\title{
Effects of Increased Myocardial Tissue Concentration of Myristic, Palmitic and Palmitoleic Acids on the Course of Cardiac atrophy of the Failing Heart Unloaded by Heterotopic Transplantation
}

\author{
M. POKORNÝ ${ }^{1}$, I. MRÁZOVÁ ${ }^{2,3}$, J. MALÝ ${ }^{1}$, J. PIRK ${ }^{1}$, I. NETUKA ${ }^{1}$, Z. VAŇOURKOVÁ ${ }^{3}$, \\ Š. DOLEŽELOVÁ ${ }^{3}$, L. ČERVENKOVÁ ${ }^{3}$, H. MAXOVÁ ${ }^{2}$, V. MELENOVSKÝ ${ }^{4}$, \\ J. ŠOCHMAN ${ }^{4}$, J. SADOWSKI ${ }^{5}$, L. ČERVENKA ${ }^{2,3}$
}

${ }^{1}$ Department of Cardiovascular Surgery, Institute for Clinical and Experimental Medicine, Prague, Czech Republic, ${ }^{2}$ Department of Pathophysiology, Second Faculty of Medicine, Charles University, Prague, Czech Republic, ${ }^{3}$ Center for Experimental Medicine, Institute for Clinical and Experimental Medicine, Prague, Czech Republic, ${ }^{4}$ Department of Cardiology, Institute for Clinical and Experimental Medicine, Prague, Czech Republic, ${ }^{5}$ Department of Renal and Body Fluid Physiology, Mossakowski Medical Research Centre, Polish Academy of Sciences, Warsaw, Poland

Received March 23, 2017

Accepted June 19, 2017

On-line November 10, 2017

\section{Summary}

The present experiments were performed to evaluate if increased heart tissue concentration of fatty acids, specifically myristic, palmitic and palmitoleic acids that are believed to promote physiological heart growth, can attenuate the progression of unloading-induced cardiac atrophy in rats with healthy and failing hearts. Heterotopic abdominal heart transplantation $\left(\mathrm{HT}_{\mathrm{x}}\right)$ was used as a model for heart unloading. Cardiac atrophy was assessed from the ratio of the native- to-transplanted heart weight $(\mathrm{HW})$. The degree of cardiac atrophy after $\mathrm{HT}_{\mathrm{x}}$ was determined on days 7, 14, 21 and 28 after $\mathrm{HT}_{\mathrm{x}}$ in recipients of either healthy or failing hearts. $\mathrm{HT}_{\mathrm{x}}$ of healthy hearts resulted in $23 \pm 3,46 \pm 3,48 \pm 4$ and $46 \pm 4 \% \mathrm{HW}$ loss at the four time-points. $\mathrm{HT}_{\mathrm{x}}$ of the failing heart resulted in even greater HW losses, of $46 \pm 4,58 \pm 3,66 \pm 2$ and $68 \pm 4 \%$, respectively $(P<0.05)$. Activation of "fetal gene cardiac program" (e.g. beta myosin heavy chain gene expression) and "genes reflecting cardiac remodeling" (e.g. atrial natriuretic peptide gene expression) after $H T_{x}$ was greater in failing than in healthy hearts $(P<0.05$ each time). Exposure to isocaloric high sugar diet caused significant increases in fatty acid concentrations in healthy and in failing hearts. However, these increases were not associated with any change in the course of cardiac atrophy, similarly in healthy and post- $\mathrm{HT}_{\mathrm{x}}$ failing hearts. We conclude that increasing heart tissue concentrations of the fatty acids allegedly involved in heart growth does not attenuate the unloading-induced cardiac atrophy.

\section{Key words}

Cardiac atrophy - Heterotopic heart transplantation • Mechanical heart unloading • Fatty acids • Heart failure

\section{Corresponding author}

L. Červenka, Center for Experimental Medicine, Institute for Clinical and Experimental Medicine, 1958/9 Vídeňská, 14000 Prague 4, Czech Republic. E-mail: luce@medicon.cz

\section{Introduction}

Implantation of left ventricle assist device (LVAD) is increasingly used in patients with end-stage heart failure (HF), mainly as a "bridge to transplantation", i.e. in patients with advanced HF waiting for cardiac transplantation (Braunwald 2015, Drakos et al. 2016, McLarty 2015). Until recently it was believed that adverse cellular, structural and functional changes in the myocardium of patients with HF ("remodeling process"), are progressive and irreversible (Braunwald 2015, Ibrahim et al. 2015). However, this belief has been shown to be inaccurate, 
because some clinical studies in HF patients after LVAD implantation indicated that long-term unloading leads to near-normalization of almost all structural and functional abnormalities of the failing myocardium, a process termed reverse remodeling (Biks 2013, Drakos et al. 2016, Chaggar et al. 2016, Ibrahim et al. 2015). Therefore, several groups have proposed that LVAD could be used as a "bridge to recovery" in the sense that patients with advanced HF after some period of LVAD support should show significant improvement of cardiac function, which would eventually make it possible to withdraw LVAD support (Drakos et al. 2016, Chaggar et al. 2016, McLarty 2015). Unfortunately, in only about 4-8 \% of HF patients with the biological signs of reverse remodeling was a clinical recovery observed (Braunwald 2015, Drakos et al. 2016, Drakos et al. 2012 Chaggar et al. 2016), and the reasons for this divergence between biological and clinical outcome have not been defined.

In this context it should be remembered that, in general, long-term mechanical unloading of the left ventricle $(\mathrm{LV})$ is known to result in severe myocardial atrophy and this also occurs with prolonged LVAD support, which critically limits application LVAD in patients with HF (Braunwald 2015, Brinks et al. 2014, Drakos et al. 2016, Drakos et al. 2012, Heckle et al. 2016, Chaggar et al. 2016, McLarty 2015, Pokorný et al. 2014). Therefore, a variety of treatment approaches were used to attenuate the progression of unloading-induced myocardial atrophy; it has to be admitted that neither approach proved satisfactory (Brinks et al. 2014, Geenen et al. 1994, Heckle et al. 2016, Klein et al. 1991, Navaratnarajah et al. 2014, Pokorný et al. 2014).

The heart is a complex living structure with a high degree of plasticity that allows, in response to mechanical, neurohormonal and chemical signals, development of adaptive changes that lead either to hypertrophy or atrophy of the myocardium. Recent studies suggest that these adaptive processes can be fully reversed (Bloomekatz et al. 2016, Dorn et al. 2007, Lee et al. 2016, Razeghi et al. 2006). The most striking example in nature of physiological hypertrophy, one that might have a potential clinical implication for the LVAD-induced cardiac atrophy, was described in Burmese pythons (Python molurus) (Andersen et al. 2005, Riquelme et al. 2011, Secor et al. 1995). It was found that this snake, which in the fasting state is inactive and hypothermic, responds to consumption of a large meal by pronounced cardiac hypertrophy (a more than $40 \%$ increase in LV mass within $48 \mathrm{~h}$ ). This is associated with a robust activation of pathways of fatty acid transport and oxidation followed by increases in plasma and tissue concentrations of myristic, palmitic and palmitoleic acids. It has been proposed that these increases in fatty acid concentrations are responsible for physiological heart growth in pythons (Riquelme et al. 2011). In addition, it was reported than chronic infusion of a mixture of myristic, palmitic and palmitoleic acids promotes physiological heart growth, not only in fasted pythons but also in normotensive mice (Riquelme et al. 2011). Given these facts, we hypothesized that activation of pathways of fatty acid oxidation with subsequent increases in myocardial concentrations of the aforementioned fatty acids should attenuate the development of unloading-induced cardiac atrophy.

To test this hypothesis, we first aimed to examine the effects of dietary-induced increases in myocardial concentration of myristic, palmitic and palmitoleic acids on the course of cardiac atrophy, which develops after heterotopic transplantation of the heart $\left(\mathrm{HT}_{\mathrm{x}}\right)$ onto the abdominal aorta of an isogenic rat recipient. In this most commonly used model which simulates mechanical unloading of the heart (Brinks et al. 2014, Geenen et al. 1994, Klein et al. 1991, Navaratnarajah et al. 2014, Ono et al. 1969, Koláŕ et al. 1993, Kolář et al. 1996, Pokorný et al. 2014, Rakušan et al. 1997), we assessed the dietary effects on normal and failing hearts derived from healthy animals or from those with advanced HF.

The second aim of the present study was to further elucidate the possible role in the development of myocardial atrophy of the expression of "fetal cardiac genes" (i.e. the cardiac gene expression of contractile proteins and metabolic enzymes) (Depre et al. 1998, Depre et al. 1999, Taegtmeyer et al. 2010), and of the degree of cardiac fibrosis which develops in response to mechanical unloading of normal and failing hearts. Furthermore, the effects on the relevant parameters of increased myocardial concentration of myristic, palmitic and palmitoleic acids were determined.

\section{Methods}

Ethical approval, animals, heterotopic heart transplantation (HTx), HF model and diets

The studies were performed in accordance with guidelines and practices established by the Animal Care and Use Committee of the Institute for Clinical and Experimental Medicine, Prague, and of the Second Faculty of Medicine, Charles University, Prague, which accord 
with the European Convention on Animal Protection and Guidelines on Research Animal Use. The present study used adult male Lewis rats, an inbred strain in which no need for post-transplantation immunosuppression is required, at the initial age of 10 weeks and body weight 270-290 g. The rats were purchased from Charles River Laboratories (Velaz, Prague, Czech Republic). The animals were kept on a 12-hour/12-hour light/dark cycle. Control rats were fed a normal salt, normal protein diet $(0.45 \% \mathrm{NaCl}, 19-21 \%$ protein) manufactured by SEMED (Prague, Czech Republic) and had free access to tap water. In order to increase myocardial concentrations of fatty acids, appropriate experimental groups were fed an isocaloric high sugar diet $(70 \%$ calories as sucrose, $20 \%$ calories as protein and $10 \%$ calories as non-sucrose carbohydrate), also manufactured by SEMED. This diet was previously used in our laboratory (Cahova et al. 2012). The heterotopic $\mathrm{HT}_{\mathrm{x}}$, originally described by Ono and Lindsey (Ono and Lindsey 1969) and employed by many groups, was used as the model to mimic the consequence of heart mechanical unloading (Brinks et al. 2014, Geenen et al. 1994, Klein et al. 1991, Kolář et al. 1993, Kolář et al. 1996, Rakušan et al. 1997). HF was induced by volume overload from aorto-caval fistula (ACF) created using needle technique as described and used by our group (Abassi et al. 2011, Beneš et al. 2011, Červenka et al. 2016, Garcia et al. 1990, Melenovský et al. 2012). Ten weeks after HF induction, ACF animals were used as heart donors; previous studies including ours demonstrated that at that time ACF animals still displayed advanced, but compensated HF, and without treatment they would soon show progression toward decompensated hypertrophy and HF (Abassi et al. 2011, Červenka et al. 2016, Melenovský et al. 2012). Sham-operated rats were used as donors of healthy hearts.

\section{Experimental design}

Series 1: Assessment of effects of high sugar diet on myocardial concentrations of fatty acids after heterotopic HTx (healthy and failing hearts)

The aim was to examine if high sucrose load in isocaloric diet would actually increase myocardial concentrations of fatty acids, with particular interest for the degree and dynamics of activation of fatty acids in the LV. Donor animals were anesthetized by inhalation of $2 \%$ isoflurane (Forane, AbbVie Ltd., Prague, Czech Republic). Recipient animals were anesthetized with thiopental sodium - $50 \mathrm{mg} \cdot \mathrm{kg}^{-1}$ of body weight i.p. (Thiopental, VUAB Pharma Ltd., Brno, Czech Republic), and heterotopic $\mathrm{HT}_{\mathrm{x}}$ of either normal or failing heart was performed as described previously (Brinks et al. 2014, Geenen et al. 1994, Klein et al. 1991, Ono et al. 1969, Kolář et al. 1993, Kolář et al. 1996, Rakušan et al. 1997). Immediately after $\mathrm{HT}_{\mathrm{x}}$ the animals were fed standard or high sucrose diet, depending on the protocol. The concentrations of fatty acids were analyzed in the LV by gas chromatography, as described in detail in previous studies, using the method standardized in our department (Cahova et al. 2012, Kahleova et al. 2016). Briefly, lipids were extracted with chloroform and separated by thin-layer chromatography using hexane-diethyletheracetic acid (80:20:3, v/v) as a solvent. The lipid esters were transmethylated with methanol. Fatty acid methyl esters were separated with gas chromatography using Hewlett-Packard GC system (HP 5890A GC, USA), with hydrogen as carrying gas. The proportions of fatty acids are given as the percentage of the sum of fatty acids analyzed.

The fatty acids concentrations in LV were evaluated 7, 14, 21 and 28 days after heterotopic $\mathrm{HT}_{\mathrm{x}}$. The following experimental groups were examined ( $n=9$ in each group):

1-4. Recipient $+\mathrm{HT}_{\mathrm{x}}$ of healthy donor's heart + standard diet for 7, 14, 21 and 28 days,

5-8. Recipient $+\mathrm{HT}_{\mathrm{x}}$ of failing heart + standard diet for 7, 14, 21 and 28 days,

9-12. Recipient $+\mathrm{HT}_{\mathrm{x}}$ of healthy donor's heart + high sugar diet for 7, 14, 21 and 28 days,

13-16. Recipient $+\mathrm{HT}_{\mathrm{x}}$ of failing heart + high sugar diet for 7, 14, 21 and 28 days.

Series 2: Effects of diet-induced increases in myocardial concentrations of myristic, palmitic and palmitoleic acids on the course of cardiac atrophy after heterotopic HTx (healthy and failing hearts)

Animals were prepared as described in series 1 and the primary aim was to evaluate the process of cardiac atrophy. The degree of cardiac atrophy was determined 7, 14, 21 and 28 days after heterotopic $\mathrm{HT}_{\mathrm{x}}$ as the weight of total heart and, separately, its individual structural components [i.e. $\mathrm{LV}+$ septum and right ventricle $(\mathrm{RV})]$, as well as the ratio of the transplanted-tohealthy or transplanted-to-failing heart weight. The healthy heart was the native heart of the recipient whereas the failing heart was the native heart of HF animals at an appropriate week (experimental groups \#18 to 26 below). This was done so because only healthy Lewis rats could be used as recipients: the animals 10 to 14 weeks 
after induction of ACF already develop decompensated $\mathrm{HF}$ and would not survive the surgical procedure. Therefore native hearts from groups \#18 to 26 were used for the calculation as mentioned above. The following experimental groups were examined ( $\mathrm{n}=9$ in each group):

1. Rats 10 weeks after sham operation,

2-5. Recipient $+\mathrm{HT}_{\mathrm{x}}$ of healthy donor's heart + standard diet for 7, 14, 21 and 28 days,

6-9. Recipient $+\mathrm{HT}_{\mathrm{x}}$ of failing heart + standard diet for 7, 14, 21 and 28 days,
10-13. Recipient $+\mathrm{HT}_{\mathrm{x}}$ of healthy donor's heart + high sugar diet for 7, 14, 21 and 28 days,

14-17. Recipient $+\mathrm{HT}_{\mathrm{x}}$ of failing heart + high sugar diet for 7, 14, 21 and 28 days,

18-22. HF rats 10,11, 12, 13 and 14 weeks after creation of $\mathrm{ACF}+$ standard diet,

23-26. HF rats 11, 12, 13 and 14 weeks after creation of ACF + high sugar diet.

The experimental design for series 1 and 2 is outlined in Figure 1.

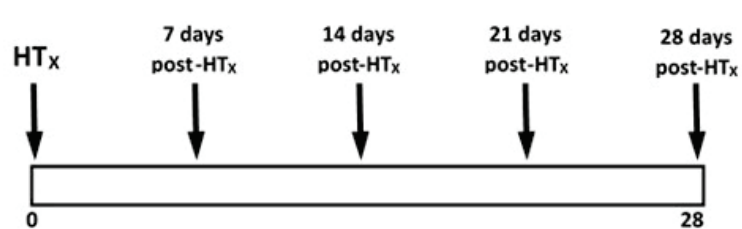

Recipient $+\mathrm{HT}$ x of healthy heart + standard diet

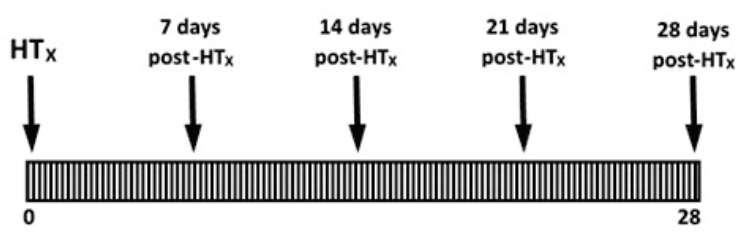

Recipient + HTx of healthy heart + high sugar diet

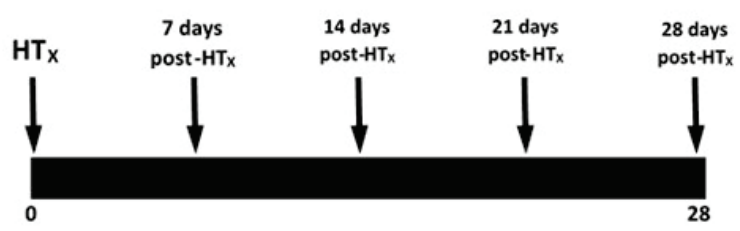

Recipient $+\mathrm{HT}$ of failing heart + standard diet

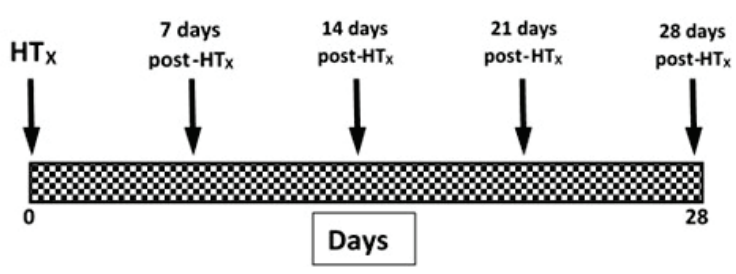

Recipient $+\mathrm{HT}_{\mathrm{x}}$ of failing heart + high sugar diet

Fig. 1. An outline of the set of groups within the experimental series 1 and 2 : healthy animals and animals with heart failure elicited by creation of the aorto-caval fistula (ACF) after heterotopic heart transplantation $\left(\mathrm{HT}_{\mathrm{x}}\right)$, fed either standard diet or isocaloric high sugar diet.

At the end of experiments, the hearts were excised, blood was removed by gentle compression, and wet weights were determined. The ratio of heart weight (HW) (either total or LV and RV) to tibia length (TL), the most suitable index of cardiac hypertrophy (Vaňourková et al. 2006, Yin et al. 1982), was used here.

Separate experimental groups $(\mathrm{n}=7$ in each) were used for histological examination of the myocardium as described previously (Kolář et al. 1996, Hampl et al. 2015). Briefly, rats were anesthetized with a combination of midazolam 5 mg. $\mathrm{kg}^{-1}$ (Dormicum, Roche Ltd., Prague, Czech Republic) and ketamine $50 \mathrm{mg} \cdot \mathrm{kg}^{-1}$ (Calypsol,
Gedeon Richter Ltd., Budapest, Hungary) i.p. Beating organs, i.e. the native heart (from the chest) and the heart after $\mathrm{HT}_{\mathrm{x}}$ (from the abdomen) were perfused in situ with $20 \mathrm{ml}$ of Thomas cardioplegia solution and subsequently fixed in $4 \%$ paraformaldehyde in phosphate buffered saline and embedded into Tissue-Tek. The blocks were cut using a cryomicrotome and cardiomyocyte width was measured in the subendocardium, midmyocardium and subepicardium of the LV. The cardiomyocyte length was measured only in the midmyocardium. In each layer 50 cardiomyocytes were assessed. To avoid underestimation, only the cells in which the nucleus was 
visible were measured. Since there were no significant differences in the cardiomyocyte width between the layers, the data from the subendocardium, midmyocardium and subepicardium were pooled (Beneš et al. 2011). Analysis of LV and RV fibrosis was performed in sections stained with Picrosirius red (Direct Red 80, Sigma Aldrich, MO, USA) as described in detail previously (Kolář et al. 1996, Hampl et al. 2015). Briefly, the interstitial collagen was analyzed in polarized light using 10 images of the LV and 5 images of a RV scanned from a midmyocardium, without perivascular areas (magnification 200x, microscope Nikon eclipse Ni-E, camera Nikon DS-L3, Tokyo, Japan). The percent area of myocardial fibrosis was calculated semiquantitatively, using the imaging software NIS-Elements Ar (LIM, Prague, Czech Republic). The measurements of the cardiomyocyte width and length, and of the degree of myocardial fibrosis were performed 7 and 28 days after heterotopic $\mathrm{HT}_{\mathrm{x}}$.

In addition, samples of LV myocardium were frozen in liquid nitrogen and stored at $-80^{\circ} \mathrm{C}$ until analysis of "fetal cardiac gene" expressions, as described in detail previously, was performed on days 7 and 28 after heterotopic $\mathrm{HT}_{\mathrm{x}}$. The relative gene expression was calculated by the $\Delta \Delta \mathrm{Ct}$ method and results were expressed as the $\mathrm{n}$-fold difference in gene expression relative to $\beta$-actin mRNA of the transplanted-to-control heart (i.e. native heart, normal or the one from animals with $\mathrm{HF}$ at an appropriate week); this was done as described in our previous studies (Hampl et al. 2015, Jíchová et al. 2016). We measured isoform-specific transcription of myosin heavy chain (MHC), specifically, expressions of "adult" isoform $\alpha(\alpha \mathrm{MHC})$ and "fetal" isoform $\beta \quad$ ( $\beta \mathrm{MHC})$ and sarcoendoplasmatic $\mathrm{Ca}^{2+}$-adenosine triphosphatase pumps (SERCA) as paradigm of genes controlling "cardiac contractility efficiency"; expressions of glucose transporters type 1 (GLUT1), type 4 (GLUT4) and carnitine palmitoyltransferase I (CPT I), as paradigm of genes controlling "cardiac substrate uptake and substrate oxidation"; expressions of atrial natriuretic peptide (ANP), transforming growth factor $\beta 1$ (TGF $\beta 1$ ) and fibroblast growth factor type 2 (FGF-2) as paradigm genes generally reflecting pathological remodeling of the heart (Depre et al. 1998, Depre et al. 1999, Taegtmeyer et al. 2010).

The primers were designed by Primer3 software and purchased from Generi Biotech Ltd. (Hradec Králové, Czech Republic). Primer sequences are collected in Table 1.

Table 1. Gene-specific primer sequences used for quantitative real-time polymerase chain reaction (PCR) used in this study.

Forward-primer 5'-3'

$\begin{array}{llc}\alpha M H C & \text { AGTCAGAGAAGGAGCGCCTA } & \text { GGACACGATCTTGGCCTTGA } \\ \beta M H C & \text { CTGGAGCAGCAAGTGGATGA } & \text { GTCAGCTTCAGGTCACCCTC } \\ \text { SERCA } & \text { TTGTGGCCCGAAACTACCTG } & \text { GGGCTGGAAGATGTGTTGCT } \\ \text { GLUT1 } & \text { CTGTAGGGCTGGACCTTTGG } & \text { AATGGAGCCTGGACCCCTAT } \\ \text { GLUT4 } & \text { TACCGTCTTCACGTTGGTCTC } & \text { TAACTCATGGATGGAACCCGC } \\ C P T I & \text { GGACAGCAGGCACATTGTTG } & \text { TGGCTCTGAGGGATCATCCA } \\ A N P & \text { TGGAGGAGAAGATGCCGGTA } & \text { CTGAGACGGGTTGACTTCCC } \\ T G F \beta 1 & \text { CTTTGTACAACAGCACCCGC } & \text { TAGATTGCGTTGTTGCGGTC } \\ F G F-2 & \text { CGCACCCTATCCCTTCACAG } & \text { GCCTTCCACCCAAAGCAGTA }\end{array}$

Reversed-primer 5'-3'

aMHC, alpha myosin heavy chain; $\beta M H C$, beta myosin heavy chain; SERCA, sarcoendoplasmatic $\mathrm{Ca}^{2+}$-adenosine triphosphatase pumps; GLUT1, glucose transporter type 1; GLUT4, glucose transporter type 4; CPT I, carnitine palmitoyltransferase I; ANP, atrial natriuretic peptide; TGF $\beta 1$, transforming growth factor $\beta 1$; FGF-2, fibroblast growth factor type 2.

The total number of animals employed in all series of the present study was 891 , including recipient and donor animals in individual experimental groups.

\section{Statistical Analyses}

All values are expressed as mean \pm SEM. Using the Graph-Pad Prism software (Graph Pad Software, San Diego, CA, USA), statistical analysis was done by Student's t-test, Wilcoxon's signed-rank test for unpaired data, or one-way analysis of variance (ANOVA) when appropriate. Values exceeding the $95 \%$ probability limits $(\mathrm{P}<0.05)$ were considered statistically significant. 


\section{Results}

As shown in Figure 2A, on day 28 after $\mathrm{HT}_{\mathrm{x}}$ exposure to high sugar diet elicited significant increases in LV myristic acid concentrations, both in hearts from healthy rats and in those with ACF-induced HF. Figures $2 \mathrm{~B}$ and $2 \mathrm{C}$ show that high sugar diet caused significant increases in LV palmitic and palmitoleic acids concentrations, again both in the healthy and failing hearts, beginning from day 7 after $\mathrm{HT}_{\mathrm{x}}$. In the case of $\mathrm{LV}$ palmitoleic acid, there was a progressing concentration increase throughout the experiment, and on day 28 the values were substantially higher than on day 7 (Fig. 2C).
A

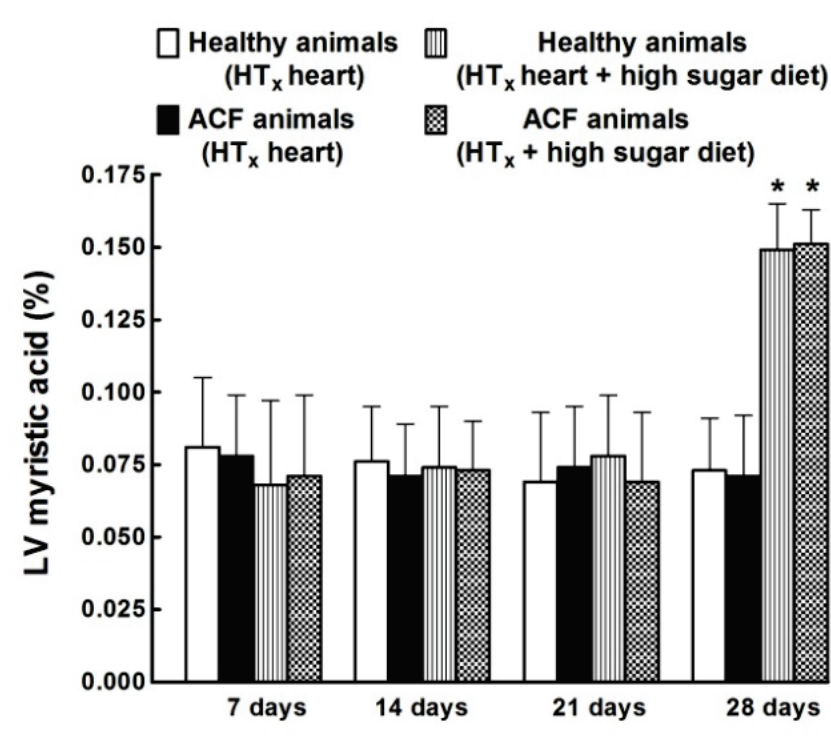

C

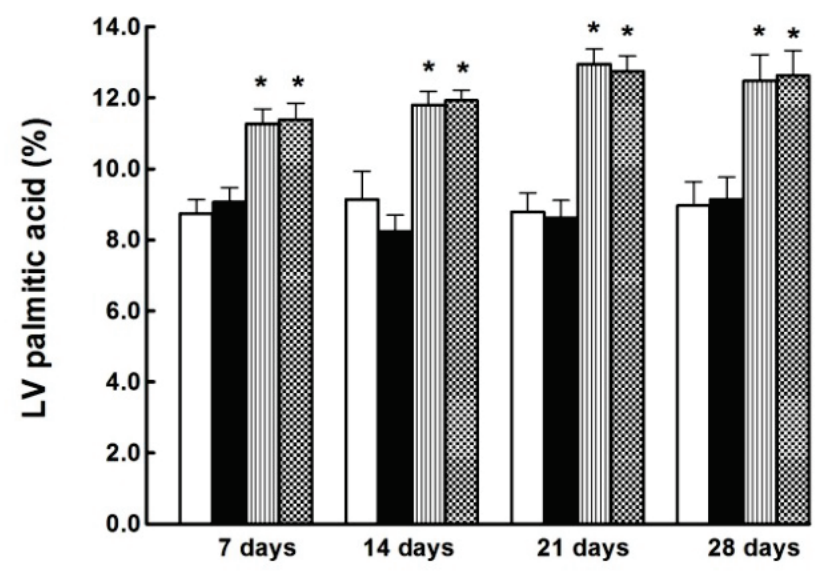

Fig. 2. Left ventricle (LV) myristic (A), palmitic (B) and palmitoleic (C) acid concentration in healthy animals and in animals with heart failure elicited by creation of the aorto-caval fistula (ACF) after heterotopic heart transplantation $\left(H T_{x}\right)$, fed either standard diet or isocaloric high sugar diet. The concentrations of the three fatty acids are expressed as the percentage of total fatty acids concentrations at each time point. $* P<0.05$ versus unmarked animals at the same time point.

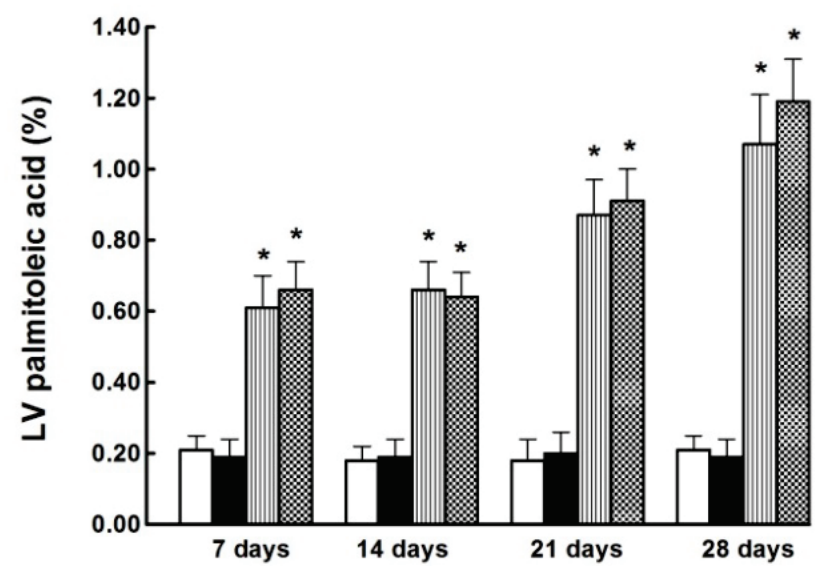


Table 2 collects the basal values of BW and the weights of the heart and its individual structural components in healthy (sham-operated) rats fed either standard or isocaloric high sucrose diet; no significant differences in these values were seen. This is important, because they served as reference values for evaluation of the degree of cardiac atrophy in healthy age-matched animals after $\mathrm{HT}_{\mathrm{x}}$. Ultimately, the percent ratio for the native orthotopic (data shown in the Table 2) to heterotopically transplanted heart weight (the latter not shown in the Table 2) were employed as an index for evaluation of the course of cardiac atrophy after $\mathrm{HT}_{\mathrm{x}}$.

Table 3 summarizes the same parameters in animals with heart failure: it is seen that LV and RV hypertrophy occurred within 14 weeks from ACF creation. Since these values are used as the reference for calculation of the index for evaluation of cardiac atrophy (see the paragraph above), it is important to recognize that the index values describing the process of cardiac atrophy after $\mathrm{HT}_{\mathrm{x}}$ in animals with ACF-induced $\mathrm{HF}$ reflect coinciding changes in the orthotopic native heart (denominator) and in the heterotopically transplanted heart (numerator).

As shown in Figure 3A, seven days of heart unloading in healthy animals caused a marked decrease (from the $100 \%$ baseline) in whole HW (-23 $\pm 3 \%$ ), which became greater on day 14 after $\operatorname{HT}_{\mathrm{x}}(-46 \pm 2 \%)$ and then remained stable on days 21 and 28 after $\mathrm{HT}_{\mathrm{x}}$ The respective changes in $\mathrm{LV}$ weight displayed an almost identical pattern (Fig. 3B). As shown in Figure 2C, the respective changes in $\mathrm{RV}$ followed a similar pattern but, surprisingly, were more pronounced: on day 7 after $\mathrm{HT}_{\mathrm{x}}$ the decrease in healthy animals was already $-47 \pm 5 \%$. In healthy animals, high sugar diet did not alter the course of whole HW, LVW and RVW decreases after $\mathrm{HT}_{\mathrm{x}}$ at any time point (Fig. 3A, 3B and 3C).

Table 2. Basal characteristics of body weight and total heart and its individual structural components either in absolute numbers or normalized to tibia length that served as basal values for the evaluation of the process of cardiac atrophy in healthy age-matched animals.

\begin{tabular}{|c|c|c|c|c|c|c|c|}
\hline \multirow[t]{2}{*}{ Group } & \multicolumn{7}{|c|}{ Parameter } \\
\hline & $\begin{array}{l}\text { BW } \\
(\mathrm{g})\end{array}$ & $\begin{array}{l}\text { HW } \\
\text { (mg) }\end{array}$ & $\begin{array}{l}\text { LVW } \\
\text { (mg) }\end{array}$ & $\begin{array}{l}\text { RVW } \\
\text { (mg) }\end{array}$ & $\begin{array}{l}\text { HW/TL } \\
(\mathrm{mg} / \mathrm{mm})\end{array}$ & $\begin{array}{l}\text { LVW/TL } \\
(\mathrm{mg} / \mathrm{mm})\end{array}$ & $\begin{array}{l}\text { RVW/TL } \\
(\mathrm{mg} / \mathrm{mm})\end{array}$ \\
\hline $\begin{array}{l}\text { Lewis rats } 10 \text { weeks after sham } \\
\text { operation }+ \text { standard diet }\end{array}$ & $317 \pm 11$ & $1,049 \pm 23$ & $669 \pm 11$ & $216 \pm 8$ & $29.11 \pm 0.82$ & $18.51 \pm 0.49$ & $5.98 \pm 0.29$ \\
\hline $\begin{array}{l}\text { Lewis rats }+H T_{x} \text { of healthy heart for } \\
7 \text { days }+ \text { standard diet }\end{array}$ & $324 \pm 12$ & $1,021 \pm 25$ & $672 \pm 17$ & $221 \pm 10$ & $28.54 \pm 0.81$ & $18.77 \pm 0.51$ & $6.17 \pm 0.31$ \\
\hline $\begin{array}{l}\text { Lewis rats }+H T_{x} \text { of healthy heart for } \\
14 \text { days }+ \text { standard diet }\end{array}$ & $339 \pm 9$ & $1,027 \pm 19$ & $674 \pm 18$ & $210 \pm 9$ & $26.69 \pm 0.92$ & $18.83 \pm 0.57$ & $5.87 \pm 0.32$ \\
\hline $\begin{array}{l}\text { Lewis rats }+H T_{x} \text { of healthy heart for } \\
21 \text { days }+ \text { standard diet }\end{array}$ & $347 \pm 11$ & $1,047 \pm 22$ & $684 \pm 19$ & $209 \pm 9$ & $29.33 \pm 0.99$ & $19.16 \pm 0.62$ & $5.86 \pm 0.37$ \\
\hline $\begin{array}{l}\text { Lewis rats }+H T_{x} \text { of healthy heart for } \\
28 \text { days }+ \text { standard diet }\end{array}$ & $361 \pm 6^{*}$ & $1,066 \pm 21$ & $679 \pm 20$ & $213 \pm 11$ & $29.58 \pm 0.91$ & $18.84 \pm 0.67$ & $5.91 \pm 0.41$ \\
\hline $\begin{array}{l}\text { Lewis rats }+H T_{x} \text { of healthy heart for } \\
7 \text { days }+ \text { high sucrose diet }\end{array}$ & $321 \pm 8$ & $1,042 \pm 25$ & $687 \pm 21$ & $208 \pm 9$ & $28.78 \pm 0.74$ & $18.98 \pm 0.54$ & $5.74 \pm 0.43$ \\
\hline $\begin{array}{l}\text { Lewis rats }+H T_{x} \text { of healthy heart for } \\
14 \text { days }+ \text { high sucrose diet }\end{array}$ & $336 \pm 10$ & $1,051 \pm 21$ & $683 \pm 20$ & $214 \pm 11$ & $29.44 \pm 0.68$ & $19.13 \pm 0.64$ & $5.99 \pm 0.47$ \\
\hline $\begin{array}{l}\text { Lewis rats }+H T_{x} \text { of healthy heart for } \\
21 \text { days }+ \text { high sucrose diet }\end{array}$ & $344 \pm 12$ & $1,063 \pm 22$ & $668 \pm 21$ & $217 \pm 12$ & $29.69 \pm 0.83$ & $18.66 \pm 0.61$ & $6.06 \pm 0.49$ \\
\hline $\begin{array}{l}\text { Lewis rats }+H T_{x} \text { of healthy heart for } \\
28 \text { days }+ \text { high sucrose diet }\end{array}$ & $363 \pm 8 *$ & $1,061 \pm 19$ & $677 \pm 18$ & $219 \pm 13$ & $28.81 \pm 0.81$ & $19.02 \pm 0.55$ & $6.15 \pm 0.42$ \\
\hline
\end{tabular}

Values are means $\pm \mathrm{SEM}$. ACF, aorto-caval fistula; BW, body weight; $\mathrm{HT}_{\mathrm{x}}$, heterotopic heart transplantation; HW, heart weight; LVW, left ventricle weight; RVW, right ventricle weight; $T L$, tibia length. ${ }^{*} \mathrm{P}<0.05$ vs. Lewis rats 10 weeks after sham-operation. 
Table 3. Basal characteristics of body weight and total heart and its individual structural components either in absolute numbers or normalized to tibia length that served as basal values for the evaluation of the process of cardiac atrophy in age-matched animals with heart failure.

\begin{tabular}{|c|c|c|c|c|c|c|c|}
\hline \multirow[t]{2}{*}{ Group } & \multicolumn{7}{|c|}{ Parameter } \\
\hline & $\begin{array}{l}\text { BW } \\
(\mathrm{g})\end{array}$ & $\begin{array}{l}\text { HW } \\
\text { (mg) }\end{array}$ & $\begin{array}{l}\text { LVW } \\
\text { (mg) }\end{array}$ & $\begin{array}{l}\text { RVW } \\
\text { (mg) }\end{array}$ & $\begin{array}{l}\text { HW/TL } \\
(\mathrm{mg} / \mathrm{mm})\end{array}$ & $\begin{array}{l}\mathrm{LVW} / \mathrm{TL} \\
(\mathrm{mg} / \mathrm{mm})\end{array}$ & $\begin{array}{l}\text { RVW/TL } \\
(\mathrm{mg} / \mathrm{mm})\end{array}$ \\
\hline $\begin{array}{l}\text { ACF Lewis rats } 10 \text { weeks after } \\
\text { induction of } A C F+\text { standard diet }\end{array}$ & $377 \pm 11$ & $2,096 \pm 71$ & $1,265 \pm 51$ & $469 \pm 37$ & $58.22 \pm 1.24$ & $35.13 \pm 0.97$ & $13.03 \pm 0.51$ \\
\hline $\begin{array}{l}\text { ACF Lewis rats } 11 \text { weeks after } \\
\text { induction of } A C F+\text { standard diet }\end{array}$ & $386 \pm 12$ & $2,302 \pm 84$ & $1,349 \pm 59$ & $538 \pm 52$ & $64.31 \pm 1.19$ & $37.68 \pm 0.61$ & $15.03 \pm 0.48^{*}$ \\
\hline $\begin{array}{l}\text { ACF Lewis rats } 12 \text { weeks after } \\
\text { induction of } A C F+\text { standard diet }\end{array}$ & $396 \pm 13$ & $2,642 \pm 66^{*}$ & $1,479 \pm 41 *$ & $552 \pm 36^{*}$ & $73.19 \pm 0.98 *$ & $41.31 \pm 0.39 *$ & $15.29 \pm 0.33 *$ \\
\hline $\begin{array}{l}\text { ACF Lewis rats } 13 \text { weeks after } \\
\text { induction of } A C F+\text { standard diet }\end{array}$ & $431 \pm 8$ & $2,697 \pm 59^{*}$ & $1,516 \pm 39 *$ & $685 \pm 32 *$ & $75.55 \pm 0.36^{*}$ & $42.47 \pm 0.27 *$ & $19.19 \pm 0.41^{*}$ \\
\hline $\begin{array}{l}\text { ACF Lewis rats } 14 \text { weeks after } \\
\text { induction of } A C F+\text { standard diet }\end{array}$ & $433 \pm 9$ & $2,689 \pm 61^{*}$ & $1,512 \pm 42 *$ & $682 \pm 44 *$ & $74.91 \pm 0.41 *$ & $42.21 \pm 0.33 *$ & $19.01 \pm 0.47^{*}$ \\
\hline $\begin{array}{l}\text { ACF Lewis rats } 11 \text { weeks after } \\
\text { induction of } A C F+\text { high sucrose diet }\end{array}$ & $384 \pm 12$ & $2,291 \pm 57$ & $1,332 \pm 40$ & $536 \pm 41$ & $63.29 \pm 0.49$ & $36.79 \pm 0.38$ & $14.81 \pm 0.39$ \\
\hline $\begin{array}{l}\text { ACF Lewis rats } 12 \text { weeks after } \\
\text { induction of } A C F+\text { high sucrose diet }\end{array}$ & $391 \pm 11$ & $2,614 \pm 59^{*}$ & $1,462 \pm 42 *$ & $557 \pm 48 *$ & $72.61 \pm 0.68^{*}$ & $40.61 \pm 0.31$ * & $15.47 \pm 0.35 *$ \\
\hline $\begin{array}{l}\text { ACF Lewis rats } 13 \text { weeks after } \\
\text { induction of } A C F+\text { high sucrose diet }\end{array}$ & $437 \pm 9$ & $2,687 \pm 61^{*}$ & $1,506 \pm 47 *$ & $681 \pm 41^{*}$ & $75.06 \pm 0.59^{*}$ & $42.07 \pm 0.33^{*}$ & $19.02 \pm 0.41 *$ \\
\hline $\begin{array}{l}\text { ACF Lewis rats } 14 \text { weeks after } \\
\text { induction of } A C F+\text { high sucrose diet }\end{array}$ & $439 \pm 11$ & $2,697 \pm 55^{*}$ & $1,537 \pm 42 *$ & $692 \pm 38^{*}$ & $75.13 \pm 0.44 *$ & $42.81 \pm 0.28^{*}$ & $19.28 \pm 0.36^{*}$ \\
\hline
\end{tabular}

Values are means \pm SEM. Values are means \pm SEM. ACF, aorto-caval fistula; BW, body weight; HW, heart weight; LVW, left ventricle weight; RVW, right ventricle weight; TL, tibia length. * $P<0.05$ vs. ACF Lewis rats 10 and 11 weeks after induction of ACF.

Figures 3D, 3E and 3F summarize the course of cardiac atrophy and the effects of high sugar diet on this process after $\mathrm{HT}_{\mathrm{x}}$ in hearts with ACF-induced HF. In general, in failing hearts the pattern of changes was similar as observed in healthy hearts, but at each time point the decreases in the whole HW and LVW were about $20 \%$ more pronounced. In addition, it should be noticed that decreases in RV weight in failing hearts progressed up to day 21 after $\mathrm{HT}_{\mathrm{x}}$. Dissimilarly, in healthy hearts the maximum decreases in RV weight were already seen on day 7 after $\mathrm{HT}_{\mathrm{x}}$. It is emphasized that compared with animals treated with standard diet the exposure to isocaloric high sucrose diet did not have any effect on the course of cardiac atrophy after $\mathrm{HT}_{\mathrm{x}}$ in ACF animals.

Figure 4 summarizes the process of cardiomyocyte atrophy in the LV of healthy animals and animals with ACF-induced HF, both groups fed standard diet. As shown, mechanical unloading of the heart after
$\mathrm{HT}_{\mathrm{x}}$ resulted in significant cardiomyocyte atrophy in the LV of healthy animals (A) as well as of animals with ACF-induced HF (B). Exposure to high sugar diet did not alter the course of this process and the data are not been included in figure. Notably, cardiomyocyte width in the LV of animals with ACF-induced HF were on days 7 and 28 (i.e. 11 and 14 weeks after induction of ACF) significantly higher than those measured in sham-operated healthy animals $(+18 \pm 2$ and $+19 \pm 3 \%$, respectively, $\mathrm{P}<0.05$ in both cases) (Figs $4 \mathrm{~A}$ and $4 \mathrm{~B}$ ).

Figure 5 summarizes the data on the index of myocardial fibrosis (\%) in the LV and RV. It shows that the degree of fibrosis was significantly lower in both ventricles of ACF animals as compared with healthy animals on day 7 , and for the LV it was also significantly lower on day 28 of the observation period. As shown in Figure $4 \mathrm{D}$, in the RV of the ACF animals after $\mathrm{HT}_{\mathrm{x}}$ the degree of myocardial fibrosis on day 28 increased to values observed in the RV of healthy animals. 
A
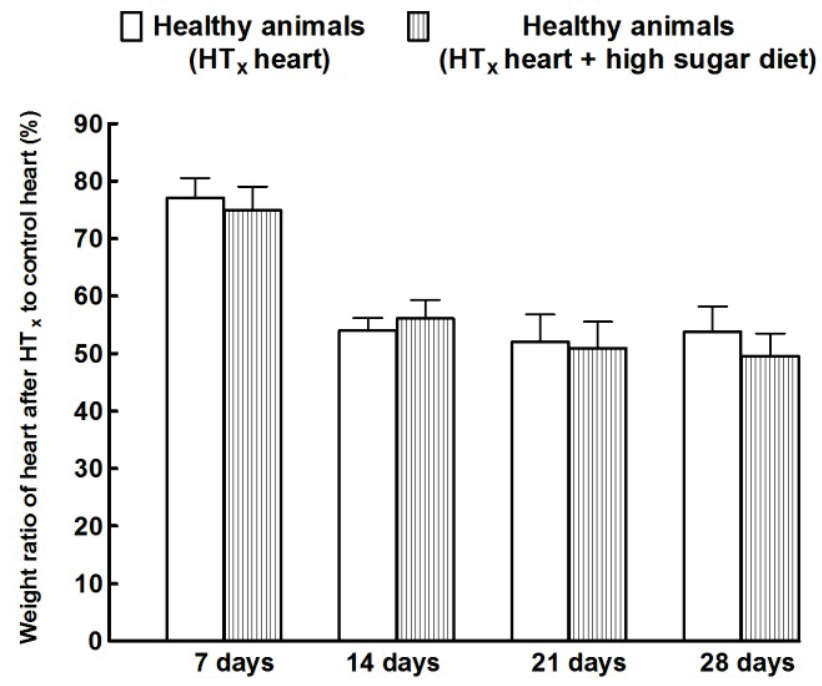

B

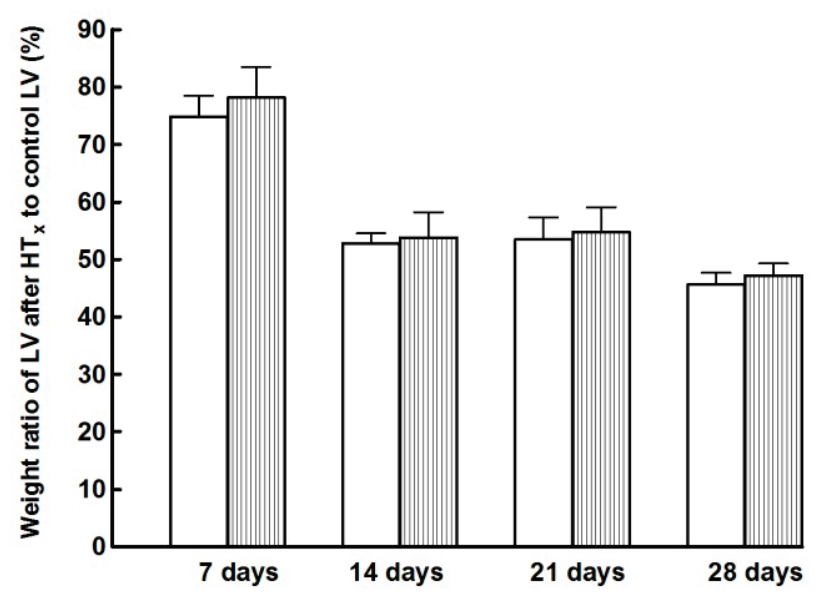

C

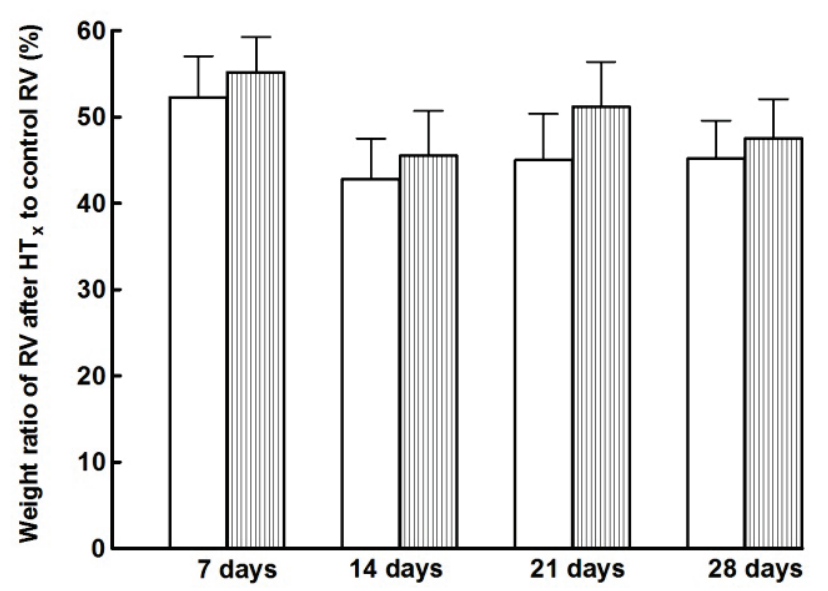

D
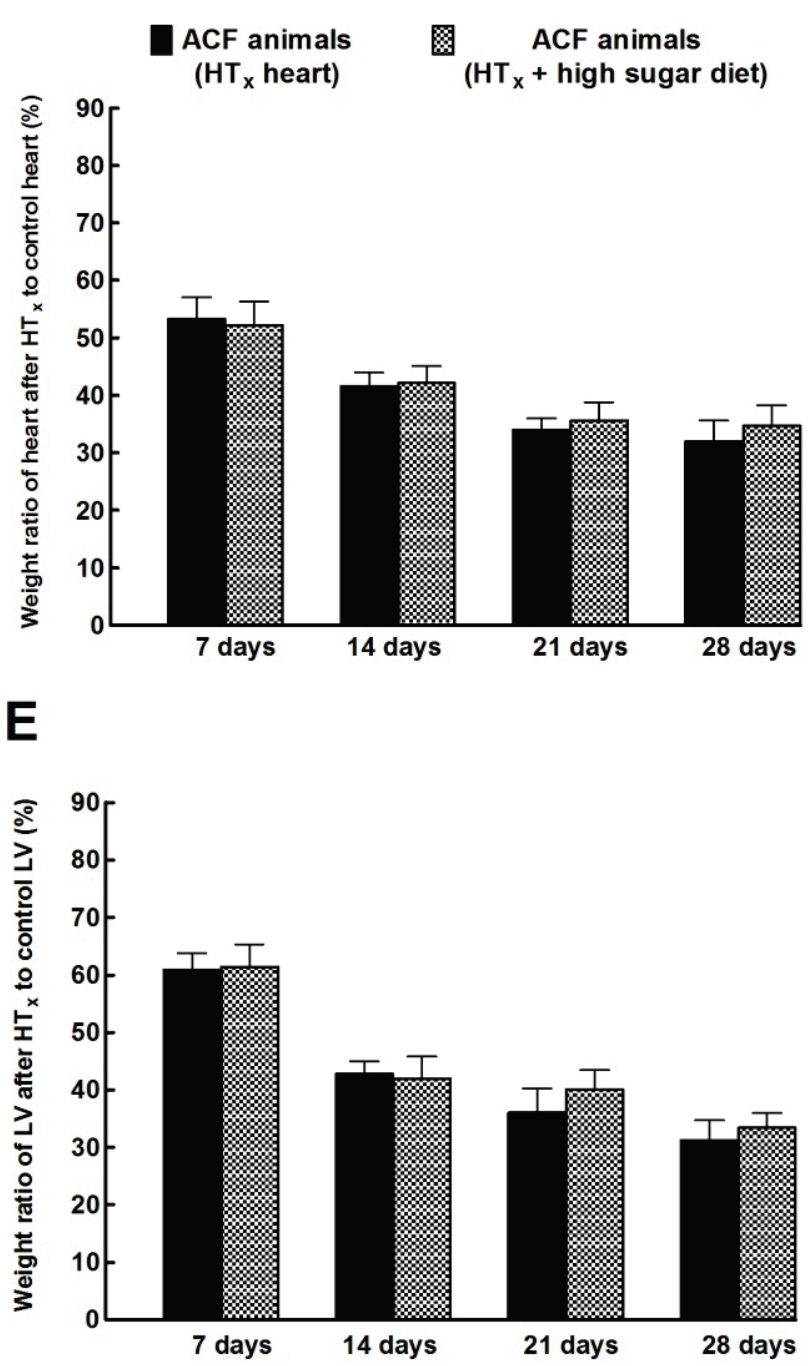

$\mathbf{F}$

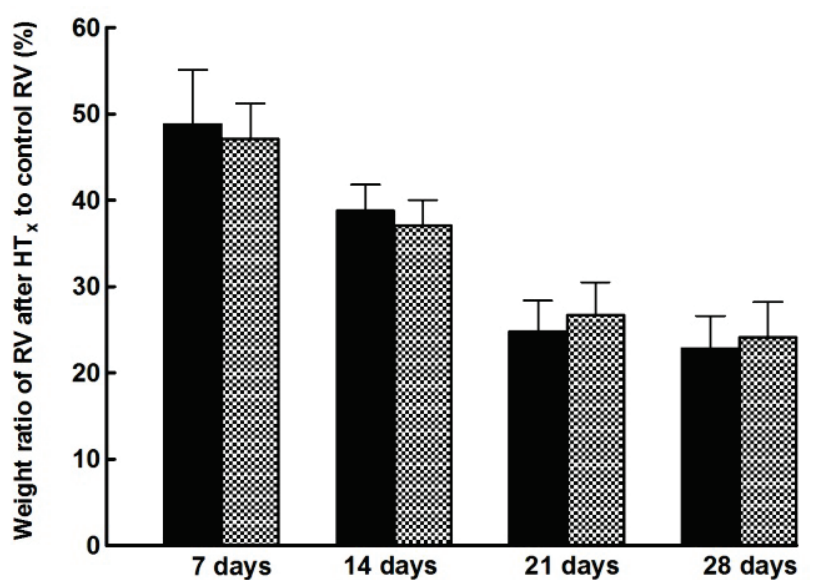

Fig. 3. Effects of exposure to isocaloric high sugar diet on the course of cardiac atrophy induced by mechanical unloading of the heart. Data expressed as the weight ratio of heterotopically transplanted heart $\left(H T_{x}\right)$ to native (control) heart, in healthy animals and in animals with heart failure elicited by creation of the aorto-caval fistula (ACF): (A and D) changes of the whole heart, (B and E) changes in the left ventricle (LV) and (C and F) changes in the right ventricle. In none of the groups did the high sugar diet affect the atrophy indices measured. 
A

\section{$\square$ Healthy animals $\oslash$ Healthy animals \\ (native hearts) $\quad\left(\mathrm{HT}_{\mathrm{x}}\right.$ heart)}

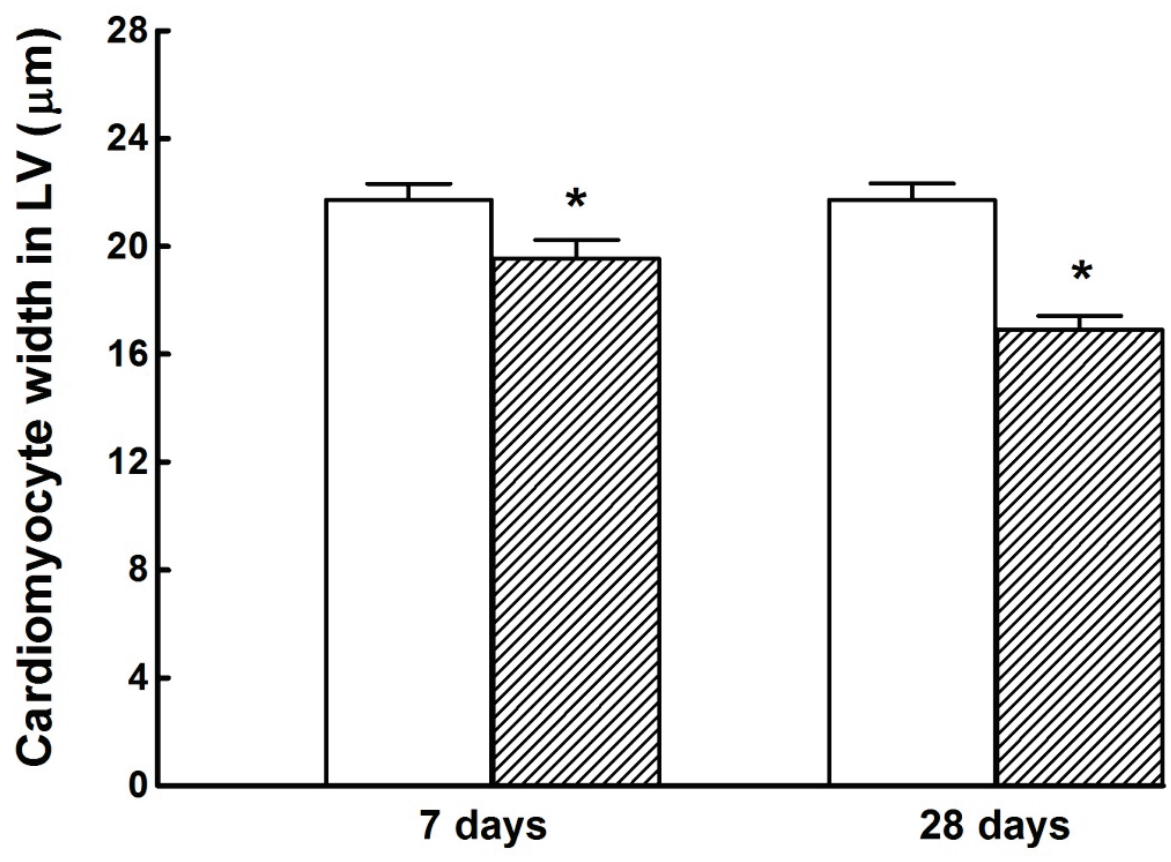

B
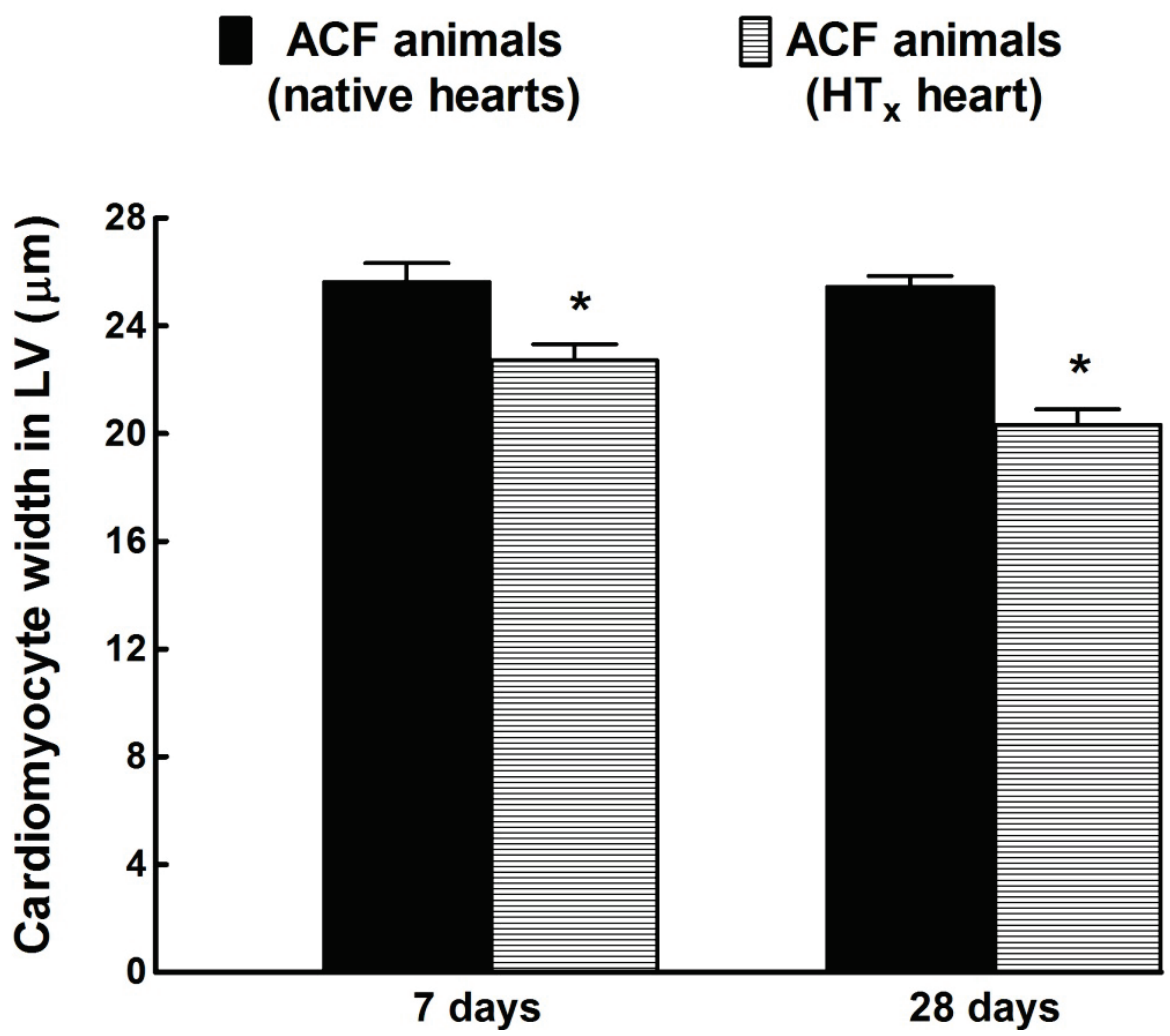

Fig. 4. Cardiomyocyte width in the mechanically unloaded heart after heterotopic heart transplantation $\left(H T_{x}\right)$, in healthy animals $(\mathbf{A})$ and in animals with heart failure (B) elicited by creation of the aorto-caval fistula (ACF). ${ }^{*} P<0.05$ versus unmarked animals at the same time point. 
A

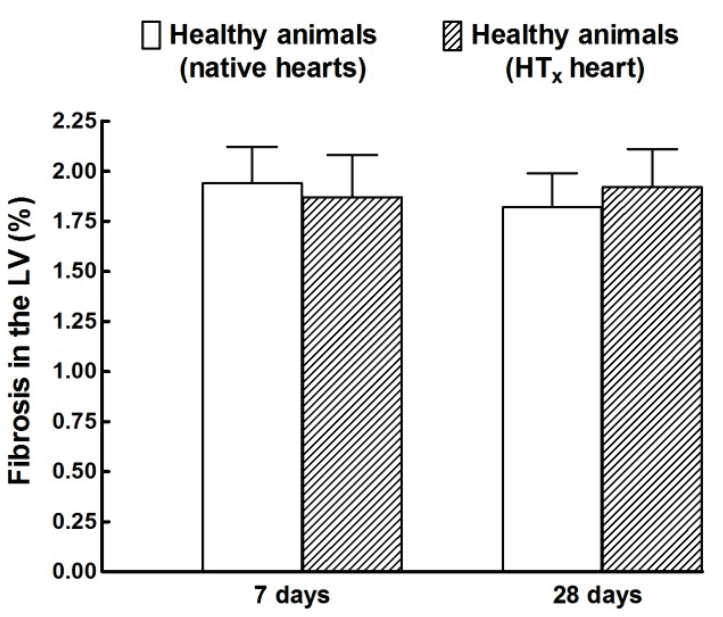

B

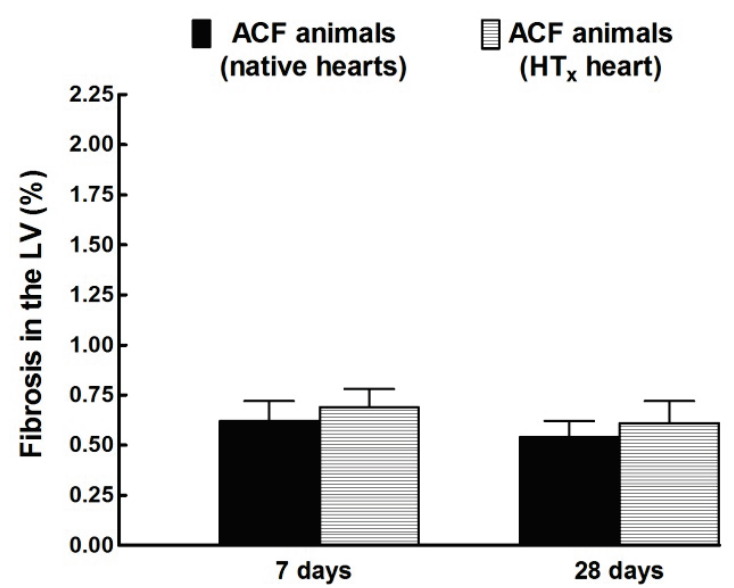

C

Healthy animals

(native hearts) $\quad\left(\mathrm{HT}_{\mathrm{x}}\right.$ heart)

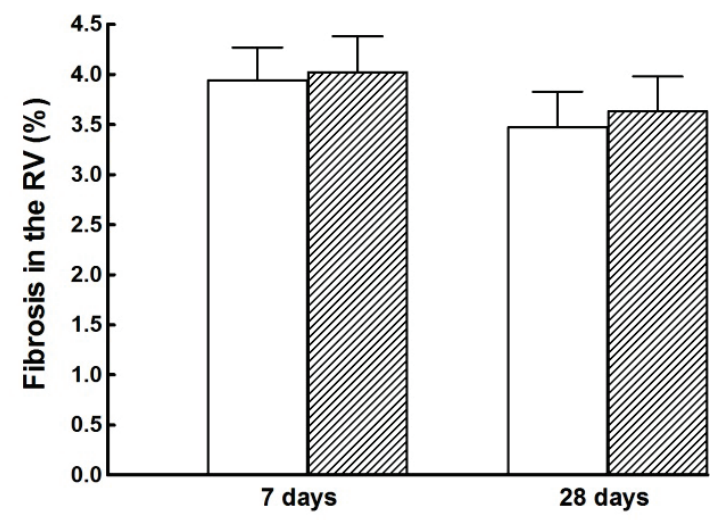

D

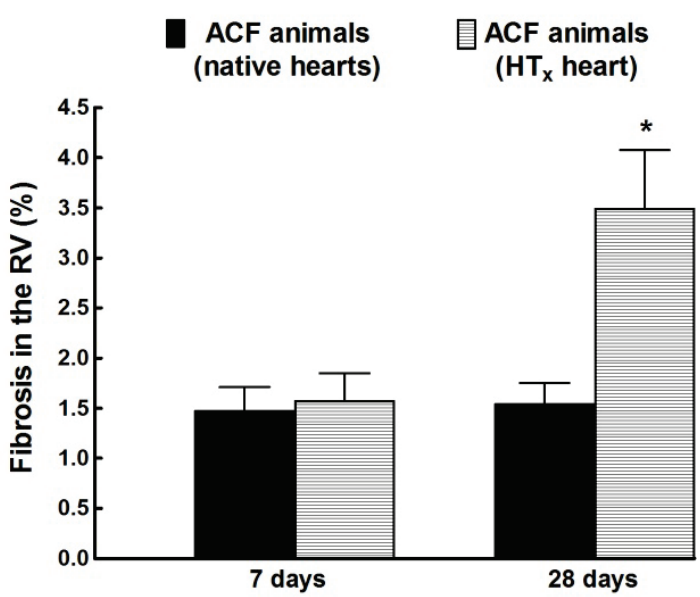

Fig 5. The degree of cardiac fibrosis in the left and right ventricle (LV, RV) of the mechanically unloaded heart after heterotopic heart transplantation $\left(\mathrm{HT}_{\mathrm{x}}\right)$, in healthy animals ( $\mathbf{A}$ and $\mathbf{C}$ ) and in animals with heart failure (B and $\mathbf{D}$ ) elicited by creation of the aorto-caval fistula (ACF). $* P<0.05$ versus unmarked animals at the same time point.

Exposure to high sugar diet did not alter the degree of myocardial fibrosis at any time point, similarly in healthy and in ACF animals, and the data are not included in the Figure 5.

As shown in Figure 6A, there were no significant differences in the LV aMHC gene expression between healthy animals and animals with ACF-induced $\mathrm{HF}$ at any time point. Mechanical unloading of the heart after $\mathrm{HT}_{\mathrm{x}}$ resulted in significant decreases in the $\alpha \mathrm{MHC}$ gene expression in healthy as well as ACF animals ( $\mathrm{P}<0.05$ at each time point), in the case of the latter the decrease on day 28 was greater than on day 7 after $\mathrm{Ht}_{\mathrm{x}}$.

As shown in Figure 6B, there were no significant differences in the LV $\beta \mathrm{MHC}$ gene expression between healthy animals and animals with ACF-induced HF, similarly on day 7 or 28 . Mechanical unloading of the heart after $\mathrm{HT}_{\mathrm{x}}$ caused a significant rise in the LV $\beta \mathrm{MHC}$ gene expression already on day 7 , both in healthy and $\mathrm{ACF}$ animals, but the change was more pronounced in the latter $(\mathrm{P}<0.05$ at each time point $)$.
As shown in Figure 6C, there were no significant differences in the LV SERCA gene expression between healthy animals and animals with ACF-induced HF at any time point. When measured on day 7 , mechanical unloading of the heart after $\mathrm{HT}_{\mathrm{x}}$ did not change the LV SERCA gene expression in healthy animals, but it did so in ACF animals. On day 28 there were significant decreases in the LV SERCA gene expression in healthy as well as ACF animals after $\mathrm{HT}_{\mathrm{x}}$, but the decrease was greater in the latter.

As shown in Figure 6D, LV GLUT1 gene expression was significantly lower in animals with ACF-induced HF than in healthy animals, similarly on day 7 and 28. Mechanical unloading did not alter the LV GLUT1 gene expression in healthy animals but elicited profound decreases in ACF animals, on day 7 as well as on day 28. The same pattern of gene expressions and their changes were observed for GLUT4 and CPT I (data not shown). 
A

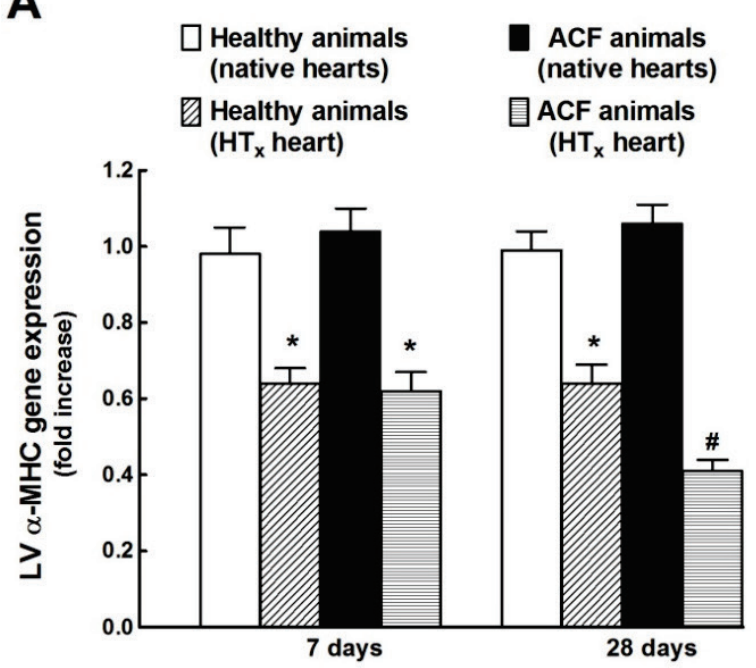

B

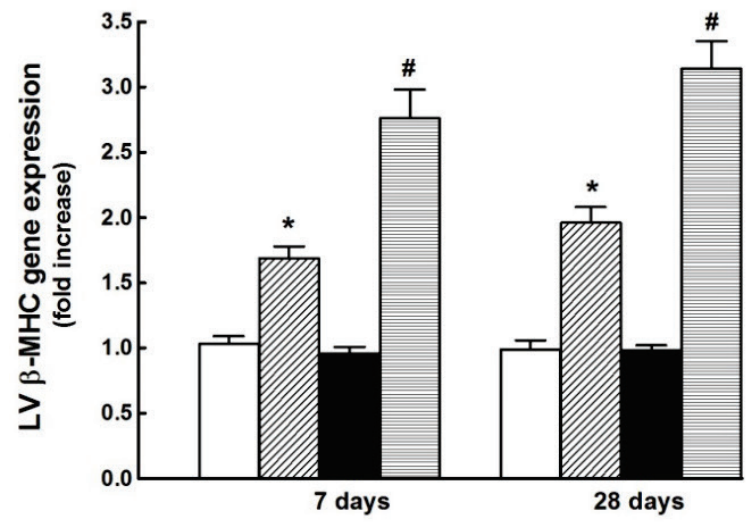

C

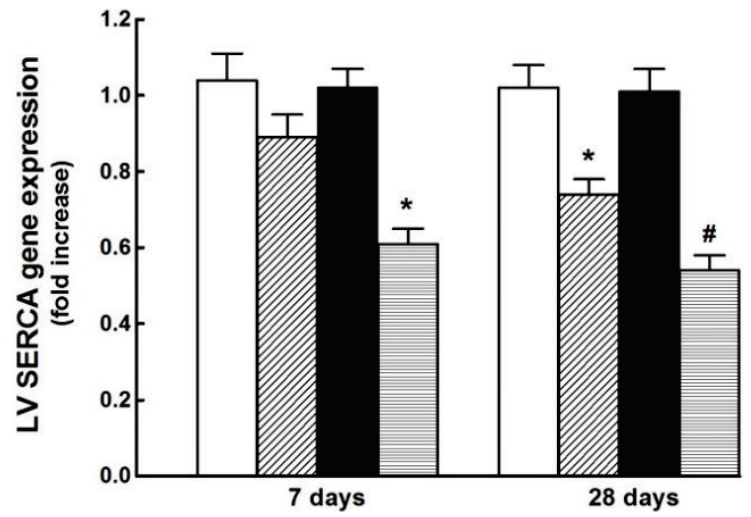

D

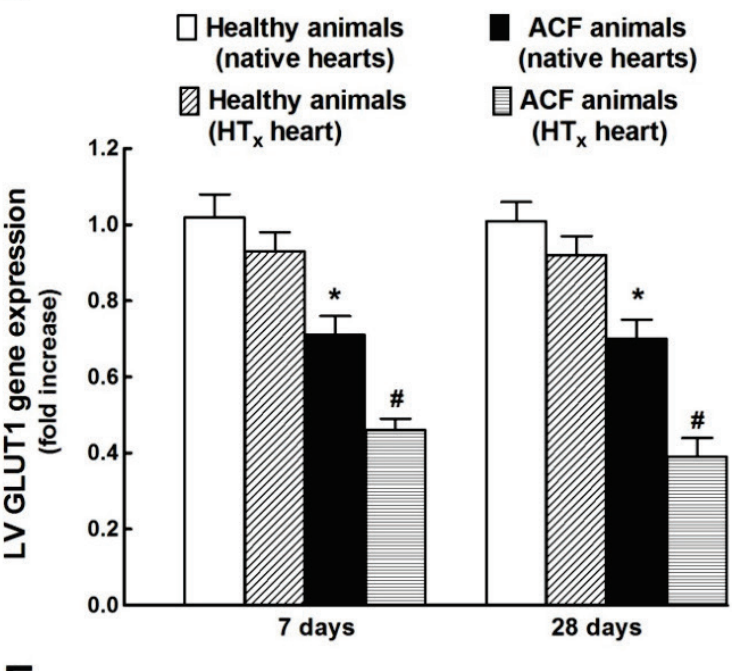

$\mathbf{E}$

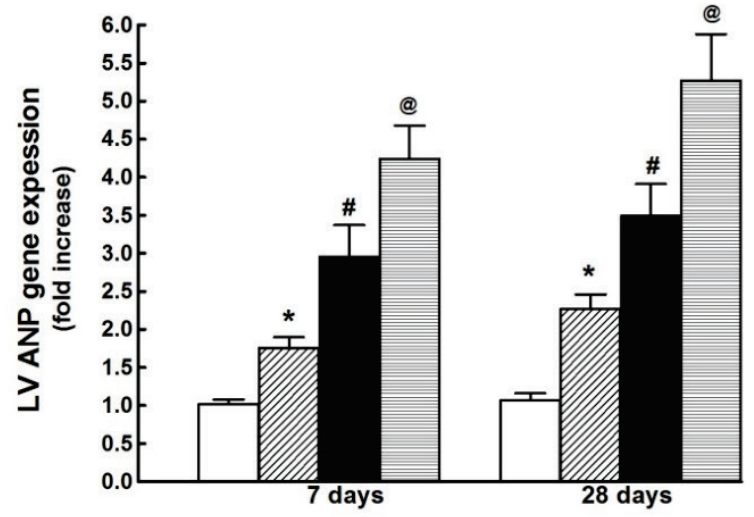

$\mathbf{F}$

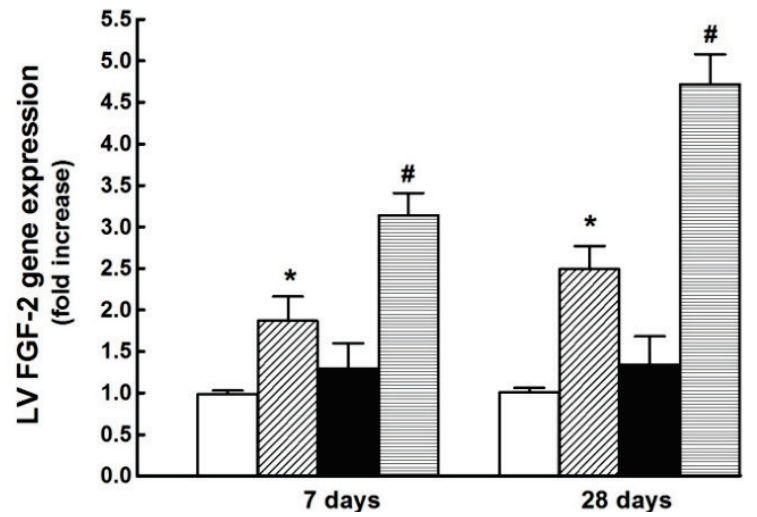

Fig. 6. The left ventricle (LV) alpha-myosin heavy chain $(\mathrm{aMHC})(\mathbf{A})$, beta-MHC $(\beta M H C)(\mathbf{B})$, sarcoendoplasmatic $\mathrm{Ca}^{2+}$-adenosine triphosphatase pumps (SERCA) (C), glucose transporter type 1 (GLUT1) (D), atrial natriuretic peptide (ANP) (E), and fibroblast growth factor type 2 (FGF-2) (F) gene expressions in the mechanically unloaded heart after heterotopic heart transplantation $\left(\mathrm{HT}_{\mathrm{x}}\right)$, in healthy animals and in animals with heart failure elicited by creation of the aorto-caval fistula (ACF). $* P<0.05$ versus native hearts from healthy animals at the same time point. ${ }^{*} \mathrm{P}<0.05$ versus ${ }^{*}$ marked values at the same time point. ${ }^{\circledR} \mathrm{P}<0.05$ versus all values at the same time point.

As shown in Figure 6E, LV ANP gene expression was significantly higher in animals with ACF-induced HF than in healthy animals at any time point. Mechanical unloading of the heart after $\mathrm{HT}_{\mathrm{x}}$ caused a significant rise in LV ANP gene expression in healthy as well as in ACF animals. 
As shown in Figure 6F, there were no significant differences in LVFGF-2 gene expression between healthy animals and animals with ACF-induced HF at any time point. Mechanical unloading of the heart after $\mathrm{HT}_{\mathrm{x}}$ caused a significant rise in LVFGF-2 gene expression in healthy as well as ACF animals, but the increase was markedly higher in the latter.

There were no significant differences in the LV TGF $\beta 1$ gene expression between healthy animals and animals with ACF-induced HF at any time point, and the mechanical unloading of the heart after $\mathrm{HT}_{\mathrm{x}}$ did not alter it, similarly in healthy and ACF animals (data not shown).

Exposure to high sugar diet did not significantly change the pattern of expression of any of the genes examined, in any of the experimental groups (data not included).

\section{Discussion}

The first important set of our findings relates to the putative role of myocardial fatty acids, specifically, myristic, palmitic and palmitoleic acids, in the attenuation of the development of unloading-induced cardiac atrophy. The first novel finding is that exposure to isocaloric high sugar diet elicited profound increases in these fatty acids in the LV after $\mathrm{HT}_{\mathrm{x}}$, in healthy as well as in ACF animals, and the levels of palmitic and palmitoleic acids were markedly elevated already after 7 days.

This is important in the context of the report that postprandial cardiac hypertrophy in the Burmese python was accompanied by increases in circulating and LV tissue concentrations of the above mentioned fatty acids (Riquelme et al. 2011), and that in fasting pythons intravenous infusion of the plasma from fed (not fasting) pythons or of a mixture of the three acids over 48-hour period increased heart weight to the values observed in fed pythons. Moreover, 7 days' infusion of the three acids to normotensive mice increased their LV weight whereas another mixture: of oleic, linoleic and arachidonic acids was ineffective. The authors concluded that postprandial increase in heart weight in the python is an example of "physiological" cardiac hypertrophy, and that the pro-hypertrophic effect is specific for the mixture of myristic, palmitic and palmitoleic acids. They proposed that supplementation of these fatty acids may provide a new approach to augmentation of cardiac performance in various diseases (Riquelme et al. 2011).

Our observation that isocaloric high sugar diet substantially increased LV tissue concentration of myristic, palmitic and palmitoleic acids strengthened our working hypothesis that application of the diet should at least attenuate the development of unloading-induced cardiac atrophy. This would accord with the recent concept that atrophied cardiomyocytes, in contrast to the widely shared belief, have the potential for the rescue and recovery (Heckle et al. 2016).

Somewhat unexpectedly we found, however, that although isocaloric high sugar diet substantially increased LV fatty acid concentrations, the increase did not attenuate the course of unloading-induced cardiac atrophy after $\mathrm{HT}_{\mathrm{x}}$. Evidently, our original hypothesis that diet-induced increases in myocardial concentrations of myristic, palmitic and palmitoleic acids, indicating activation of adaptive physiological hypertrophic process (Riquelme et al. 2011), potentially a novel approach for attenuating the process of unloading-induced cardiac atrophy was not corroborated. Several aspects and reasons of this failure should be considered.

First, the role of some direct or indirect effects of, broadly speaking, "metabolic factors" on the course of unloading-induced cardiac atrophy after $\mathrm{HT}_{\mathrm{x}}$ can be excluded: a major advantage of the heterotopic $\mathrm{HT}_{\mathrm{x}}$ model is that the transplanted heart is exposed to the same hormonal environment as the control (i.e. orthotropic native) heart. The transplanted organ is supplied by the recipient's blood, and we did not observe any alterations in the cardiac weight of native hearts in healthy or ACF animals.

Second, attention should be given to the largely overlooked studies that are in conflict with the reports on an "obligatory" postprandial cardiac hypertrophy in pythons, and suggest that such postprandial cardiac hypertrophy is a "facultative" response (Slay et al. 2014). In the newest study in Ball pythons (Python regius) during digestion cardiac weight did not increase and cardiac contractility per se was not affected (Enok et al. 2016). Admittedly, this was so in a python strain different from that in which a marked postprandial cardiac hypertrophy was repeatedly described (Anderson et al. 2005, Riquelme et al. 2011, Secor et al. 1995). Moreover, a recent study suggests that factors other than circulating signal molecules, such as free fatty acids, are involved in the process of postprandial cardiac hypertrophy in pythons, and that increased cardiac work, mechanical stress and myocardial oxygen consumption are the main stimuli for the growth. This notion accords with the studies reported more than 25 years ago, showing that 
inflation in the LV of a latex balloon provided an isovolumic load which prevented heart atrophy after $\mathrm{HT}_{\mathrm{x}}$ (Klein et al. 1993). This was the only successful attempt to fully prevent unloading-induced cardiac atrophy but, unfortunately, not applicable in the clinic: in patients with LVAD the procedure would cause obstruction of the LV and failure of LVAD. Nevertheless, this study further supports the concept that elevated cardiac work is required to trigger postprandial hypertrophy via common physiological hypertrophy signaling pathways (Slay et al. 2014).

Third, it is important to recognize that even though vertebrates moved from an aquatic to a terrestrial environment more than 350 million years ago, important differences in the reptiles persisted (e.g. reptiles remained poikilothermic), and the reptilian and mammalian heart still differ in their response to various physiological challenges. Moreover, reptiles exhibit some mixing of venous and arterial blood because of incomplete separation of the RV and the LV. This resembles the circumstances with ventricular septal defects, wherein the variations in the resistance of the pulmonary and/or systemic arterial tree modify the pulmonary-to-systemic flow ratio and induce either left-to-right or right-to-left intracardial shunts, leading to significant differences in cardiac output of each ventricle. It is known that in squamate hearts the RV is disproportionally larger. Even though in pythons and varanid lizards the separation of the RV and the LV is almost complete, some physiological intracardial shunting is still present (Bettex et al. 2014, Jensen et al. 2014). Therefore, some physiological differences between reptile and mammals heart might account for the different cardiac responses to diet-induced increases in myocardial concentrations of myristic, palmitic and palmitoleic acids.

Given these findings, while the hormonal or metabolic factors, such as increased concentrations of myristic, palmitic and palmitoleic acids, may contribute to the development of the postprandial hypertrophy or to the attenuation of the process of unloading-induced cardiac atrophy, they might provide only modulatory role and without an appropriate rise in cardiac work and wall stress cannot trigger the pro-hypertrophic process in the heart. Therefore, in discordance with our working hypothesis, diet-induced increases in myocardial myristic, palmitic and palmitoleic acid levels per se, without a rise in cardiac work, are not adequate stimuli to activate physiological hypertrophic processes. Thus, no attenuation of the development of unloading-induced cardiac atrophy occurred. Apparently, further studies are needed to evaluate the effects of combined metabolic and mechanical interventions (e.g. combination of increased tissue fatty acids concentration and enhancement of isovolumic loading) on the course of cardiac atrophy after $\mathrm{HT}_{\mathrm{x}}$.

The second important set of our findings relates to comparison of the course of unloading-induced cardiac atrophy in healthy and failing hearts. We found that cardiac atrophy after $\mathrm{HT}_{\mathrm{x}}$ is more prominent in failing hearts, as indicated by analysis of the HW and LVW ratios of native orthotopic-to-heterotopically transplanted hearts. Another interesting finding was that atrophy of RV in failing hearts progressively continued up to day 21 after $\mathrm{HT}_{\mathrm{x}}$ while in healthy hearts the maximum atrophy of RV was already reached on day 7 . Although we cannot explain this difference, the finding per se is of substantial interest: evidently, any pharmacological or non-pharmacological attempts to attenuate or prevent unloading-induced cardiac atrophy should be also evaluated in the failing hearts, even though preparation of the failing heart for $\mathrm{HT}_{\mathrm{x}}$ is difficult and cumbersome. The limitation of using exclusively healthy hearts in such studies was also recognized by other investigators (Brinks et al. 2014, Didié et al. 2013, Heckle et al. 2016, Klein et al. 1991, Liu et al. 2015).

The third important set of our findings relates to the expression of "fetal cardiac gene program" and the degree of cardiac fibrosis, which develops in response to mechanical unloading in healthy and failing hearts. We found no significant difference in the LV expression of genes controlling "cardiac contractility efficiency" (i.e. aMHC, $\beta \mathrm{MHC}$ and SERCA) between healthy and ACF animals. In contrast, the LV expression of genes controlling "cardiac substrate uptake and substrate oxidation" (i.e. GLUT1, GLUT4 and CPT I) was in animals with ACF-induced HF lower than in healthy animals, and the LV expression of ANP gene (a marker of the degree of pathological remodeling) was in healthy animals lower than in ACF animals. In accordance with previous studies, mechanical unloading induced typical signs of activation of "fetal gene cardiac program", and activation of genes that are thought responsible for the remodeling of the myocardium (Depre et al. 1998, Depre et al. 1999, Taegtmeyer et al. 2010). However, an entirely novel finding here is that activation of the "fetal gene cardiac program" and "genes reflecting remodeling of the heart" (i.e. ANP and FGF-2 in this case) in response to mechanical unloading was distinctly 
greater in animals with ACF-induced HF than in healthy animals. In addition, we found that the diet-induced increases in myocardial concentration of myristic, palmitic and palmitoleic acids did not alter the pattern of the LV gene expression, similarly in healthy and failing hearts after $\mathrm{HT}_{\mathrm{x}}$. This is important because, initially, after the discovery that the remodeling process of the atrophied or hypertrophied heart includes a return to the "fetal gene program" (Depre et al. 1998, Depre et al. 1999, Taegtmeyer et al. 2010), the dominant view has been that a return to the fetal gene program is detrimental and a hallmark of progressive deterioration in cardiac functions (Bloomekatz et al. 2016, Ibrahim et al. 2015, Soppa et al. 2008). In accordance with this claim it was even distinguished between "physiological" and "pathological" hypertrophy (Dorn 2007, Lee et al. 2016). Clenbuterol, a selective $\beta_{2}$-adrenergic agonist, was reported to elicit "physiological" hypertrophy (i.e. without activation of "fetal gene program"), in contrast to isoproterenol, a $\beta_{1}$ - and $\beta_{2}$-agonist (Wong et al. 1998). Therefore, chronic clenbuterol treatment was advocated for pharmacological prevention of cardiac atrophy and improvement of myocardial function during mechanical unloading (Birks 2013, Navaratnarajah et al. 2014), however, the treatment was without success (Drakos et al. 2016, Pokorný et al. 2014). It will also be noticed that chronic clenbuterol treatment during $\mathrm{HT}_{\mathrm{x}}$-induced LV unloading was reported to prevent the expression of the "fetal gene program" and increased $\beta$-adrenergic responsiveness but completely failed to attenuate the course of cardiac atrophy (Tsuneyoshi et al. 2005). Therefore, it was proposed that the expression of the "fetal gene program" is a purely adaptive process and does not imply, per se, irreversible cell damage and, in fact, it is a cardioprotective response.

Our present findings show that the expression of the "fetal gene program" after $\mathrm{HT}_{\mathrm{x}}$ was augmented in failing hearts when compared with healthy hearts, which indicates that the unloading-induced cardiac atrophy and activation of the "fetal gene program" run in parallel. Nevertheless, our present data do not resolve the question whether the augmented activation of the "fetal gene program" is detrimental (contributes to progression of cardiac atrophy) or an adaptive change (helps myocardium to spare energy and improves contraction, as observed in the fetal heart), which enables recovery of the atrophic myocyte in the failing heart (Heckle et al. 2016). Whichever is true, our data clearly show a strong relationship between the degree of unloading-induced cardiac atrophy and the activation of the "fetal gene program". Further studies are needed to explore this complex issue.

It is worthwhile to address some issues related to the morphology and function of the heart in the animals with ACF-induced HF. This is a model of chronic volume overload which induces eccentric cardiac hypertrophy, characterized by increased size of the cardiomyocyte. The final outcome is HF but, as indicated by our present and earlier results (Benes et al. 2011, Sedmera et al. 2016), unlike with pressure-induced concentric hypertrophy or ischemic cardiomyopathy induced by myocardial infarction, the process is not accompanied by increased myocardial fibrosis. It should be noticed that the model of ACF-induced $\mathrm{HF}$ has recently been employed with increasing frequency since it simulates the condition of many cardiovascular patients, e.g. those with mitral insufficiency, and has several key features of human HF: pronounced compensatory activation of neurohumoral systems, fluid retention, renal dysfunction and gradual transition from the asymptomatic (i.e. compensated) to the decompensated phase of HF (Braunwald 2015, Abassi et al. 2011, Benes et al. 2011, Melenovsky et al. 2012). Our present findings indicate that native hearts of ACF animals display lower LV and RV myocardial fibrosis compared with the native hearts of healthy animals. Moreover, the mechanical unloading produced by $\mathrm{HT}_{\mathrm{x}}$ did not alter the degree of myocardial fibrosis in the LV and RV in healthy hearts and in the LV of failing hearts. This was unexpected because previous studies evaluating the process of unloading-induced myocardial atrophy after $\mathrm{HT}_{\mathrm{x}}$ demonstrated that myocardial fibrosis in the LV as well as in the RV gradually increased, and this increase was reported to be a consequence of the loss of contractile mass and subsequent increased concentration of collagen, but not of its content (Didié et al. 2013, Kolář et al. 1993, Koláŕ et al. 1996, Rakusan et al. 1997). We cannot satisfactorily explain our present findings which showed that in the case of all the other parameters the course of cardiac atrophy after $\mathrm{HT}_{\mathrm{x}}$ was almost identical with that seen in previous studies employing the model which simulates mechanical unloading of the heart (Brinks et al. 2014, Geenen et al. 1994, Klein et al. 1991, Navaratnarajah et al. 2014, Ono et al. 1969, Kolář et al. 1993, Kolář et al. 1996, Rakušan et al. 1997).

We have no good explanation for the interesting finding that the degree of myocardial fibrosis in the $\mathrm{RV}$ of the post- $\mathrm{HT}_{\mathrm{x}}$ failing hearts significantly increased 
to values observed in the RV of healthy animals. Notably, this increase could lead, especially under conditions of prolonged mechanical unloading, to increased cardiac RV stiffness and impairment of systolic contraction and diastolic relaxation, with consequent RV failure: an abnormality that would compromise the possibility of weaning from LVAD treatment. This unresolved issue deserves appropriately focused research.

In conclusion, the results of the present study show, first, that the process of unloading-induced cardiac atrophy is accelerated in the failing as compared with healthy heart. Second, we found that increasing heart tissue concentration of fatty acids, specifically myristic, palmitic and palmitoleic acids does not attenuate the course of unloading-induced cardiac atrophy.

\section{Conflict of Interest}

There is no conflict of interest.

\section{Acknowledgements}

This study was primarily supported by Ministry of Health of the Czech Republic grant 16-27420A awarded to Jan Pirk.

\section{References}

ABASSI Z, GLOTSMAN I, KARRAM T, WINAVER J, HOFFMAN A: Aortocaval fistula in rat: a unique model of volume-overload congestive heart failure and cardiac hypertrophy. J Biomed Biotechnol 2011: 729497, 2011.

ANDERSEN JB, ROURKE BC, CAIOZZO VJ, HICKS J: Physiology: postprandial cardiac hypertrophy in pythons. Nature 434: 37-38, 2005.

BENEŠ J, MELENOVSKY V, SKAROUPKOVA P, POSPISILOVA P, PETRAK J, CERVENKA L, SEDMERA D: Myocardial morphological characteristics and proarrhytmic substrate in the rat model of heart failure due to chronic volume overload. Anat Rec 294: 102-111, 2011.

BETTEX DA, PRETRE R, CHASSOT PG: Is our heart a well-designed pump? The heart along animal evolution. Eur Heart J 35: 2322-2332, 2014.

BIRKS EJ: Molecular changes after left ventricular assist device support for heart failure. Circ Res 113: 777-791, 2013.

BLOOMEKATZ J, GALVEZ-SANTISTEBAN M, CHI NC: Myocardial plasticity: cardiac development, regeneration and disease. Curr Opin Genet Dev 40: 120-130, 2016.

BRAUNWALD E: The war against heart failure. Lancet 385: 812-824, 2015.

BRINKS H, GIRAUD MN, SEGISER A, FERRIÉ C, LONGNUS S, ULLRICH ND, KOCH WJ, MOST P, CARREL TP, TEVAERAI HT: Dynamic patterns of ventricular remodelling and apoptosis in hearts unloaded by heterotopic transplantation. J Heart Lung Transplant 33: 203-210, 2014.

CAHOVA M, DANKOVA H, PALENICKOVA E, PAPACKOVA E, KAZDOVA L: The opposite effects of high-sucrose and high-fat diet on fatty acids oxidation and very low density lipoprotein secretion in rat model of metabolic syndrome. J Nutr Metab 2012: 757205, 2015.

CHAGGAR PS, WILIAMS SG, YONAN N, FILDES J, VENKATESWARAN R, SHAW SM: Myocardial recovery with mechanical circulatory support. Eur J Heart Fail 18: 1220-1227, 2016.

ČERVENKA L, ŠKAROUPKOVÁ P, KOMPANOWSKA-JEZIERSKA E, SADOWSKI J: Sex-linked differences in the course of chronic kidney disease and congestive heart failure: a study in 5/6 nephrectomized Ren-2 transgenic hypertensive rats with volume overload induced using aorto-caval fistula. Clin Exp Pharmacol Physiol 43: 883-895, 2016.

DEPRE C, SHIPLEY GL, CHEN W, HAN Q, DOENST T, MOORE ML, STEPKOWSKI S, DAVIES PJ, TAEGTMEYER H: Unloaded heart in vivo replicates fetal gene expression of cardiac hypertrophy. Nat Med $\mathbf{4}$ : 1269-1275, 1998.

DEPRE C, DAVIES PJ, TAEGTMEYER H: Transcriptional adaptation of the heart to mechanical unloading. Am J Cardiol 83: 58H-63H, 1999.

DIDIÉ M, BIERMANN D, BUCHERT R, HESS A, WITTKOPPER K, CHRISTALLA P, DOKER S, JEBRAN F, SCHONDUBE F, REICHENSPURNER H, EL-ARMOUCHE A, ZIMMERMANN WH: Preservation of left ventricular function and morphology in volume-loaded versus volume-unloaded heterotopic heart transplants. Am J Physiol Heart Circ Physiol 305: H533-H541, 2013. 
DORN GW: The fuzzy logic of physiological cardiac hypertrophy. Hypertension 49: 962-970, 2007.

DRAKOS SG, KFOURY AG, STEHLÍK J, SELZMAN CH, REID BB, TERROVITIS JV, NANANS JN, LI DY: Bridge to recovery: understanding the disconnect between clinical and biological outcomes. Circulation 126: 230-241, 2012.

DRAKOS SG, MEHRA MR: Clinical myocardial recovery during long-term mechanical support in advanced heart failure: insights into moving the field forward. J Heart Lung Transplant 35: 413-420, 2016.

ENOK S, LEITE GS, GESSER H, HEDRICK MS, WANG T: Improved cardiac filling facilitates the postprandial elevation of stroke volume in Python regius. J Exp Biol 219: 3009-3018, 2016.

GARCIA R, DIEBOLD S: Simple, rapid, and effective method of producing aorto-caval shunts in the rat. Cardiovasc Res 24: 430-432, 1990.

GEENEN DL, MALHOTRA A, BUTTRICK PM, SCHEUER J: Ventricular pacing attenuates but does not reverse cardiac atrophy and an isomyosin shift in the rat heart. Am J Physiol 267: H2149-H2154, 1994.

HAMPL V, HERGET J, BÍBOVÁ J, BAŇASOVÁ A, HUSKOVÁ Z, VAŇOURKOVÁ Z, JÍCHOVÁ Š, KUJAL P, VERENEROVÁ Z, SADOWSKI J, ČERVENKA L: Intrapulmonary activation of the angiotensin-converting enzyme type 2/angiotensin 1-7/G-protein-coupled Mas receptor axis attenuates pulmonary hypertension in Ren-2 transgenic rats exposed to chronic hypoxia. Physiol Res 64: 25-38, 2015.

HECKLE MR, FLATT DM, SUN Y, MANCARELLA S, MARION TN, GERLING IC, WEBER KT: Atrophied cardiomyocytes and their potential for rescue and recovery of ventricular function. Heart Fail Rev 21: 191-198, 2016.

IBRAHIM M, NADER A, YACOUB MH, TERRACCIANO C: Manipulation of sarcoplasmic reticulum $\mathrm{Ca}^{2+}$ release in heart failure through mechanical intervention. J Physiol 593: 3253-3259, 2015.

JÍCHOVÁ Š, DOLEŽELOVÁ Š, KOPKAN L, KOMPANOWSKA-JEZIERSKA E, SADOWSKI J, ČERVENKA L: Fenofibrate attenuates malignant hypertension by suppression of the renin-angiotensin system: a study in Cyp1a1-Ren-2 transgenic rats. Am J Med Sci 352: 618-630, 2016.

JENSEN B, MOORMAN AF, WANT T: Structure and function of the hearts of lizards and snakes. Biol Rev Camb Philos Soc 89: 302-336, 2014.

KAHLEOVA H, MALINSKA H, KAZDOVA L, BELINOVA L, TURA A, HILL M, PELIKANOVA T: The effect of meal frequency on the fatty acid composition of serum phospholipids in patients with type 2 diabetes. $J \mathrm{Am}$ Coll Nutr 35: 317-325, 2016.

KLEIN I, HONG S, SCHREIBR SS: Isovolumic loading prevents atrophy of the heterotopically transplanted rat heart. Circ Res 69: 1421-1425, 1991.

KOLÁŘ F, MACNAUGHTON C, PAPOUSEK F, KORECKY B: Systolic mechanical performance of heterotopically transplanted hearts in rats treated with cyclosporine. Cardiovasc Res 27: 1244-1247, 1993.

KOLÁŘ F, PAPOUŠEK F, MACNAUGHTON C, PELOUCH V, MILEROVÁ M, KORECKY B: Myocardial fibrosis and right ventricular function of heterotopically transplanted hearts in rats treated with cyclosporine. Mol Cell Biochem 164: 253-260, 1996.

LEE LC, KASSAB GS, GUCCIONE JM: Mathematical modelling of cardiac growth and remodelling. WIREs Syst Biol Med 8: 211-226, 2016.

LIU Y, MAUREIRA P, GAUCHOTTE G, FALANGA A, MARIE V, OLIVIER A, GROUBATCH F, GU C, MARIE PY, TRAN N: Effect of chronic left ventricular unloading on myocardial remodeling: multimodal assessment of two heterotopic heart transplantation techniques. J Heart Lung Transplant 34: 594-603, 2015.

MCLARTY A: Mechanical circulatory support and the role of LVADs in heart failure therapy. Clin Med Insights Cardiol 9 (Suppl 2): 1-5, 2015.

MELENOVSKY V, SKAROUPKOVA P, BENES J, TORRESOVA V, KOPKAN L, CERVENKA L: The course of heart failure development and mortality in rats with volume overload due to aorto-caval fistula. Kidney Blood Press Res 35: 167-173, 2012.

NAVARATNARAJAH M, SIEDLECKA U, IBRAHIM M, VAN DOORN C, SOPPA G, GANDHI A, SHAH A, KUKADIA P, YACOUB MH, TERRACCIANO CM: Impact of combined clenbuterol and metoprolol therapy on reverse remodelling during mechanical unloading. PLoS One 9: e92909, 2014. 
ONO K, LINDSEY ES: Improved technique of heart transplantation in rats. J Thorac Cardiovasc Surg 57: 225-229, 1969.

POKORNÝ M, CERVENKA L, NETUKA I, PIRK J, KOŇǍ̌́IK M, MALÝ J: Ventricular assist devices in heart failure: how to support the heart but prevent atrophy? Phys Res 63: 147-156, 2014.

RAKUSAN K, HERON MI, KOLAR F, KORECKY B: Transplantation-induced atrophy of normal and hypertrophic rat hearts: effects on cardiac myocytes and capillaries. J Mol Cell Cardiol 29: 1045-1054, 1997.

RAZEGHI P, TAEGTMEYER H: Hypertrophy and atrophy of the heart. The other side of remodeling. Ann N Y Acad Sci 1080: 110-119, 2006.

RIQUELME CA, MAGIDA JA, HARRISON BC, WALL CE, MARR TG, SECOR SM, LEINWAND LA: Fatty acids identified in the Burmese python promote beneficial cardiac growth. Science 334: 528-531, 2011.

SECOR SM, DIAMOND J: Adaptive responses to feeding in Burmese pythons: pay before pumping. J Exp Biol 198: 1313-1325, 1995.

SEDMERA D, NECKAR J, BENES J JR, POSPISILOVA J, PETRAK J, SEDLACEK K, MELENOVSKY V: Changes in myocardial composition and conduction properties in rat heart failure model induced by chronic volume overload. Front Physiol 7: 367, 2016.

SLAY CE, ENOK S, HICKS JW, WANG T: Reduction of blood oxygen levels enhances postprandial cardiac hypertrophy in Burmose python (Python bivittatus). J Exp Biol 217: 1784-1789, 2014.

SOPPA GK, BARTON PJ, TERRACCIANO CM, YACOUB MH: Left ventricle assist device-induced molecular changes in the failing myocardium. Curr Opin Cardiol 23: 206-218, 2008.

TAEGTMEYER H, SEN S, VELA D: Return to the fetal gene program: a suggested metabolic link to gene expression in the heart. Ann N Y Acad Sci 1188: 191-198, 2010.

TSUNEYOSHI H, ORIYANHAN W, KANEMITSU H, SHIINA R, NISHINA T, MATSUOKA S, IKEDA T, KOMEDA M: Does the $\beta_{2}$-agonist clenbuterol help to maintain myocardial potential to recover during mechanical unloading? Circulation 112 (9 Suppl): I51-I56, 2005.

VANOURKOVA Z, KRAMER HJ, HUSKOVA Z, VANECKOVA I, OPOCENSKY M, ČERTÍKOVÁ CHÁBOVÁ V, TESAR V, SKAROUPKOVÁ P, THUMOVÁ M, DOHNALOVÁ M, MULLINS JJ, CERVENKA L: AT1 receptor blockade is superior to conventional triple therapy in protecting against end-organ damage in Cyp1a1Ren-2 transgenic rats with inducible hypertension. J Hypertens 24: 2465-2472, 2006.

YIN FC, SPURGEON HA, RAKUSAN K, WEISFELDT ML, KAKATTA EG: Use of tibial length to quantify cardiac hypertrophy: application in the aging rat. Am J Physiol 243: H941-H947, 1982.

WONG K, BOHELER KR, BISHOP J, PETROU M, YACOUB MH: Clenbuterol induces cardiac hypertrophy with normal functional, morphological and molecular features. Cardiovasc Res 37: 115-122, 1998. 